\title{
Effects of occupational exposure to dust, gas, vapor and fumes on chronic bronchitis and lung function impairment
}

\section{Xueyan Zheng}

Guangdong Provincial Center for Disease Control and Prevention

\section{Yijin Zheng}

Guangdong Pharmaceutical University

\section{Tingting Liao}

Jinan University

\section{Yanjun Xu}

Guangdong Provincial Center for Disease Control and Prevention

\section{Li Liu}

Guangdong Pharmaceutical University

\section{Ye Wang}

Guangdong Provincial Center for Disease Control and Prevention

\section{Ni Xiao}

Guangdong Provincial Center for Disease Control and Prevention

\section{Chuan Li}

Guangdong Provincial Center for Disease Control and Prevention

\section{Ruilin Meng}

Guangdong Provincial Center for Disease Control and Prevention

\section{Weijie Guan}

First Affiliated Hospital of Guangzhou Medical University

\section{Lifeng Lin ( $\sim 1396320174 @ q q . c o m$ )}

Guangdong Provincial Center for Disease Control and Prevention

\section{Zhaoxuan He}

Guangdong Provincial Center for Disease Control and Prevention

\section{Research Article}

Keywords: Dust, gas, vapor and fumes, Chronic bronchitis, Respiratory symptoms, Lung function.

Posted Date: February 11th, 2022

DOI: https://doi.org/10.21203/rs.3.rs-1288303/v1

License: (c) (i) This work is licensed under a Creative Commons Attribution 4.0 International License. Read Full License 


\section{Abstract}

Objectives: We sought to investigate the effects of occupational exposure to vapors, gases, dust and fumes (VGDF) on chronic bronchitis and lung function impairment.

Methods: We conducted chronic obstructive pulmonary disease surveillance in six cities of south China between 2014 and 2019. We recorded the diagnosis of chronic bronchitis, respiratory symptoms, occupational exposure to VGDF and other covariates by using a structured questionnaire. Logistic regression and multivariate linear regression model were adopted for analysis.

Results: A total of 7418 and 5249 participants were included. Cough (OR: 1.60, 95\%Cl: 1.22 to 2.08 ) and phlegm (OR: $1.49,95 \% \mathrm{Cl}: 1.19$ to 1.85$)$ correlated significantly with the exposure to dust. There was an increased risk of cough (OR: $1.53,95 \% \mathrm{Cl}: 1.11$ to 2.07 ) for occupational exposure to gas/vapor/fume. Dual exposure to dust and gas/vapor/fume was associated with a significantly increased risk of chronic bronchitis (OR: 1.74, 95\% Cl: 1.20 to 2.52), as well as cough (OR: $1.43,95 \% \mathrm{Cl}: 1.15$ to 1.79) and phlegm (OR: $1.49,95 \% \mathrm{Cl}: 1.24$ to 1.79). Gas/vapor/fume was associated with the reduced ratio of forced expiratory volume in one second and forced vital capacity (FEV $1 / \mathrm{FVC})(\beta:-1.05,95 \% \mathrm{Cl}:-1.85$ to $-0.26)$ and maximal mid-expiratory flow(MMEF) ( $\beta$ : $-0.15,95 \% \mathrm{Cl}:-0.23$ to -0.07$)$. Dual exposure to dust and gas/vapor/fume was significantly associated with decreased $\mathrm{FEV}_{1} / \mathrm{FVC}(\beta$ : $-0.74,95 \% \mathrm{Cl}$ : -1.28 to -0.20$)$ and MMEF ( $\beta$ : $-0.06,95 \% \mathrm{Cl}:-0.12$ to -0.01$)$. Results of sensitivity analysis did not materially change.

Conclusions: VGDF exposure was associated with chronic bronchitis, respiratory symptoms and impaired lung function, suggesting that VGDF contribute to the pathogenesis and progression of COPD.

\section{Introduction}

Chronic obstructive pulmonary disease (COPD) is one of the leading causes of mortality and morbidity worldwide [1,2], and is characterized by irreversible airflow limitation [3]. Chronic bronchitis, defined as cough and sputum production lasting for at least 3 months in two consecutive years, is the core manifestation of COPD. Chronic bronchitis has been associated with more frequent exacerbations, more rapid lung function decline and predisposes to the development of COPD [4-7]. Identification of the modifiable risk factors for the early or excessive lung function decline and the development of chronic bronchitis has important significance [8], such as vapors, gases, dust and fumes (VGDF). Only two studies have analyzed the association between occupational exposures to VGDF and chronic bronchitis based on the European Community Respiratory Health Survey (ECRHS) $[9,10]$, revealing inconsistent results.

As the main source of occupational exposure, the impact of VGDF exposure on lung function has been increasingly recognized [11-15]. Findings on the association between VGDF exposure and lung function decline have been conflicting, with some studies reporting a positive association [11-15] and some others not $[9,16]$. To date, none of the published studies has been conducted in the developing countries such as China. Further studies are warranted to provide the evidence confirming the association between occupational exposure to VGDF and airflow obstruction and lung function impairment.

In real-world scenarios, occupational exposure to dust and biomass fuel pollution may frequently co-exist. However, few studies have evaluated the association between dual exposure (dust plus gas/vapor/fumes) and respiratory symptoms and lung function impairment in developing countries. We hypothesized that occupational exposure to VGDF would contribute to more prominent lung function impairment and chronic bronchitis. Here, we sought to explore the effects of VGDF exposures on lung function impairment and chronic bronchitis in middle-aged adults and the elderly in south China. Our findings might provide further scientific evidence regarding the adverse effects of the more broadly defined occupational exposure to VGDF in the general population.

Page 2/26 


\section{Methods}

\section{Study design and participants}

Between 2014 and 2019, we adopted a multistage, probability-based sampling strategy for COPD surveillance in six districts or counties Guangdong province. The detailed methods have been described previously [17]. Briefly, residents living in the current surveillance point for at least 6 months were deemed eligible for participation. Residents with cognitive defects, language or mental disorders, cancer, paraplegia, or were pregnant or breastfeeding were excluded. Data were collected during a consultation in a healthcare facility by trained staffs from the local health stations or community clinics. The study protocol was approved by the ethics review committee of the National Center for Chronic and Non-Communicable Disease Control and Prevention, China Center for Disease Control and Prevention in 2015 and the ethics review committee of the Guangdong Provincial Center for Disease Control and Prevention in 2019. All participants had provided written informed consent.

\section{Clinical assessments}

Trained staffs conducted pre- and post-bronchodilator spirometry among all eligible participants by using commercial spirometers (MasterScreen Pneumo, Jaeger, Germany), following the international guidelines $[3,18]$. We obtained at least three technically acceptable and repeatable maneuvers for each participant. The highest values of forced expiratory volume in one second $\left(\mathrm{FEV}_{1}\right)$, forced vital capacity $(\mathrm{FVC})$, and maximal mid-expiratory flow (MMEF) were selected.

Records of respiratory symptoms, including chronic cough and phlegm, were derived from the standardized questionnaire based on the American Thoracic Society and International Study of Asthma and Allergies in Childhood $[19,20]$. Cough denoted coughing on most days in the morning or at other times (participants responding 'yes' to this question item). Phlegm denoted sputum production in the morning or at other times of most days (participants responding 'yes' to this question item). Respondents also reported the frequency of respiratory symptoms. Chronic bronchitis was defined as coughing up phlegm for at least three months in two consecutive years[21].

\section{Exposure assessment}

A standardized questionnaire was used to ascertain occupational dust exposure only, gas, vapor and fumes only, and dual occupational exposure to gas/vapor/fumes and dust. Participants were requested to answer the occupational information including the job title, industry, and the duration of work, which were associated with occupational exposure to dust and gas, vapor and fumes (See Panel 1 for details).

\section{Covariates}

We captured the following covariates from the questionnaire survey: age, sex, height, education level, marriage status, region of residence, body-mass index (BMI), smoking status and biomass fuel.

\section{Statistical analysis}

We analyzed the basic characteristics of participants in occupational dust, gas/vapor/fume and dual exposure groups. Continuous variables were demonstrated with the mean and standard deviation, and frequencies for categorical variables. The t-tests were employed to analyze the association of continuous variables, and when indicated, appropriate transformation was applied. Contingency tables and chi-squared tests were applied for categorical variables. The odds ratios (ORs) and $95 \%$ confidence intervals $(95 \% \mathrm{Cls}$ ) were calculated for the association between occupational exposure to VGDF and chronic bronchitis and individual respiratory symptoms (cough and phlegm) by using univariate and multivariate logistic regression, based on five stepwise models. Multivariate linear regression model was adopted to 
calculate the changes of forced expiratory volume in one second $\left(\mathrm{FEV}_{1}\right)$, forced vital capacity $(\mathrm{FVC})$, the ratio of $\mathrm{FEV} \mathrm{V}_{1}$ and FVC ( $\left.\mathrm{FEV}_{1} / \mathrm{FVC}\right)$ and maximal mid-expiratory flow (MMEF) in two groups with different occupational exposure status, based on the five stepwise models. The association was deemed robust if the results of all models were not modified materially. To avoid overfitting, we have also compared the Alkaike's information criterion (AIC) value of the five different models. The magnitude of colinearity was assessed based on the variance inflation factor (VIF). The VIF of 5 or greater indicated colinearity among the variables. Variables with the evidence of a significant colinearity were excluded from the model. We further conducted sensitivity analyses based on two methods of propensity score (PS) methods to evaluate the robustness of our results: 1 ) Inverse probability weighting; 2 ) including the PS score as an additional covariate.

All statistical analyses were performed with SAS software 9.4 (SAS Institute, Inc. Cary, NC. USA). The threshold for statistical significance was set to $\mathrm{P}<0.05$.

\section{Results}

\section{Baseline characteristics of study participants}

A total of 7418 and 5249 participants were included for analyzing the association between occupation exposure to VGDF and chronic bronchitis and lung function impairment, respectively (Figure 1). The baseline characteristics of the study population are summarized in Table 1. There were higher proportions of males, participants with younger age, smoking and normal BMI status among those working with exposure to dust. In addition, participants exposed to dust had a higher frequency of cough, phlegm, and had increased $\mathrm{FEV}_{1}, \mathrm{FVC}$ and $\operatorname{MMEF}(\mathrm{P}<0.05)$. Participants with occupational exposure to gas, vapor and fumes were mainly young people living in rural area, who mostly received primary school education or lower. Exposure to gas vapor and fumes was associated with cough, reduced $\mathrm{FEV}_{1} / \mathrm{FVC}$ and MMEF $(P<0.05)$. Similar findings applied to participants with dual pollution exposure. (Table 1).

\section{Association between VGDF and respiratory symptoms}

Occupational exposure to dust was associated with an increased risk of cough (OR: $1.60,95 \% \mathrm{Cl}$ : 1.22 to $2.08, \mathrm{P}=0.001$ in Model 5) and phlegm (OR: 1.49, 95\%Cl: 1.19 to 1.85, $\mathrm{P}<0.001$ in Model 5) (Table 2, Figure 2). We only noted significantly increased risk of cough (OR: 1.53, 95\% Cl: 1.11 to 2.07, $\mathrm{P}=0.008$ in Model 5) for occupational exposure to gas/vapor/fume group (Table 3, Figure 3). Notably, dual occupational exposure to dust and gas/vapor/fume was associated with significantly increased risk of chronic bronchitis (OR: 1.74, 95\% $\mathrm{Cl}: 1.20$ to 2.52, $\mathrm{P}=0.004$ in Model 5), as well as increased risk of cough (OR: 1.43, 95\% Cl: 1.15 to 1.79, $\mathrm{P}=0.001$ in Model 5) and phlegm (OR: 1.49, 95\%Cl: 1.24 to 1.79, $\mathrm{P}<0.001$ in Model 5) (Table 4, Figure 4).

Similar association between VGDF exposure and chronic bronchitis and respiratory symptoms has been observed in male (E-Table 1-3). However, the impact of VGDF exposures on chronic bronchitis and respiratory syndromes was not significant in female. After adjusting for covariates, exposure to dust was associated only with phlegm, while dual exposure was associated with cough and phlegm in female.(E-Table 4-6). The association was robust based on the consistent results from Model 1 to Model 5.

\section{Association between VGDF and lung function impairment}

We did not find significant association between occupational dust exposure and impaired lung function (Table 5, Figure 5). The association was also not found in both males and females (E-Table 7-8). Compared with those without exposure to VDGF, the mean $\mathrm{FEV}_{1} / \mathrm{FVC}$ was 1.05 lower (95\% Cl: $-1.85,-0.26, \mathrm{P}=0.01$ in Model 5), MMEF was $0.15 \mathrm{~L} / \mathrm{min}$ lower (95\% Cl: $-0.23,-0.07, \mathrm{P}<0.001$ in Model 5) in participants with occupational exposure to gas/vapor/fumes (Table 6, Figure 
6). The mean MMEF was $0.13 \mathrm{~L} /$ min lower in males (E-Table 9), while the corresponding mean $\mathrm{FEV}_{1} / \mathrm{FVC}$ and $\mathrm{MMEF}$ was 1.34 and $0.17 \mathrm{~L} / \mathrm{min}$ lower in females with occupational exposure to gas/vapor/fumes (E-Table 10). The mean FVC was $0.04 \mathrm{~L}$ higher $\left(95 \% \mathrm{Cl}\right.$ : 0.01, 0.07, $\mathrm{P}=0.004$ in Model 5), the $\mathrm{FEV}{ }_{1} / \mathrm{FVC}$ was 0.74 lower $(95 \% \mathrm{Cl}:-1.28,-0.20, \mathrm{P}=0.01$ in Model 5) and the mean MMEF was 0.06 lower (95\% Cl: $-0.12,-0.01, \mathrm{P}=0.03$ in Model 5) in participants with dual occupational exposure when compared with those without exposure to VDGF (Table 7, Figure 7). The mean FVC was 0.06 higher in males (E-Table 11), while the corresponding mean $\mathrm{FEV}_{1} / \mathrm{FVC}$ and MMEF was 0.95 and $0.09 \mathrm{~L} / \mathrm{min}$ lower in females with dual occupational exposure (E-Table 12). These results were overall consistent from Model 1 to Model 5, confirming the robustness of the associations.

\section{Sensitivity analysis}

Sensitivity analysis showed that the results were not substantially changed. We found that in the analyses which had included the PS score as an additional covariate, as well as the analysis that had included the inverse probability weighting, participants exposed to dust were consistently more likely to suffer from cough and phlegm than those who without VDGF exposure (Table 2, Figure 2). Occupational exposure to gas, vapor and fumes was also associated with phlegm based on the sensitivity analysis (Table 3, Figure 3). Participants with dual occupational exposure were more likely to develop chronic bronchitis and respiratory symptoms than those exposed to neither dust nor gas/vapor/fume (Table 4, Figure 4). The mean $\mathrm{FEV}_{1} / \mathrm{FVC}$ and MMEF were lower in participants with occupational exposure to gas/vapor/fumes and dual pollution compared with those without occupational exposure (Table 6-7, Figure 6-7).

\section{Discussion}

This cross-sectional study provides solid population-based evidence supporting the fact that simultaneous occupational exposure to VGDF increase the risk for chronic bronchitis. We found an increased risk of the salient respiratory symptoms, including cough and/or phlegm among participants with three occupational exposure groups of dust only, gas/vapor/fume only and VGDF. Furthermore, occupational exposure to gas/vapor/fume or VGDF was associated with impaired lung function.

A number of population-based studies have reported the association between dust exposure and symptoms related to chronic bronchitis[22]. However, few studies have examined the effect of dust exposure on chronic bronchitis as an important outcome. In addition, few studies have specifically examined the association between chronic bronchitis and certain occupational exposures, particularly gas, vapor and fumes. Our study has added substantially to the evidence pertaining to the association between occupational exposure to VGDF and chronic bronchitis and the individual respiratory symptoms. Similar to the finding of an earlier analysis in the cohort of ECRHS, there was an association between occupational exposures to dust and chronic phlegm but not chronic bronchitis[9]. However, the latest cohort study of ECRHS showed a positive but significant risk of mineral dust exposure and chronic bronchitis [10]. These findings indicated that the age [23], the duration of exposure and the improvement of working conditions [24,25] might have collectively explained the inconsistent findings among studies. Positive association between the exposure to gas, vapor and fume and chronic bronchitis was not demonstrated in the latest cohort study of ECRHS, which was similar to this study. A key research question is whether the adverse effects of dual occupational exposure to dust and gas/vapor/fume would be synergistic. Indeed, based on the cross-sectional survey in Guangdong province, we noted a higher risk of respiratory symptoms in participants with dual occupational exposure to VGDF when compared with those exposed to dust or gas/vapor/fumes alone. The mechanisms pertaining to the effect of occupational exposure to VGDF on chronic bronchitis and respiratory symptoms are less clear. VGDF are a heterogeneous category of exposures, which have been linked to various forms of pulmonary toxicity [26-28]. For instance, previous epidemiological and 
experimental studies of vanadium and bronchitis have documented the significant association between exposure to VGDF and chronic bronchitis [26,28].

In this study, we have evaluated the association between occupational exposures and chronic bronchitis symptoms of cough and phlegm separately, which were less specific to chronic bronchitis. Although some studies have documented that the VGDF inhalation exposure did not lead to the development of chronic cough $[10,29,30]$ or chronic phlegm [29,30], we have now identified the associations between VGDF and multiple respiratory symptoms including cough and phlegm, which mirrored the previous findings. A cohort study demonstrated that occupational exposure to VGDF resulted in the respiratory symptoms related to bronchitis [31-33]. Another population-based study has demonstrated an association between occupational exposure to VGDF and chronic cough and phlegm [34]. Moreover, we found that the effects of VGDF exposures on cough, phlegm and bronchitis varied between males and females. Further study is warranted to confirm the differential association between males and females.

This study provided the evidence that occupational exposure to gas/vapor/fume or VDGF were significantly associated with the trend towards airway obstruction (decreased $\mathrm{FEV}_{1} / \mathrm{FVC}$ ). Previous studies have provided some evidence for an association between VGDF exposure and lower levels of lung function, but the findings remained largely contradictory. Several cross-sectional studies [35-37] and a longitudinal study [38] did not suggest an association between exposure to VGDF and accelerated lung function decline. Although a cohort study from ECRHS-1 used the lifetime work history to assign exposure to VGDF, revealing that it was related to chronic phlegm and a lack of information on lung function decline or airway obstruction [9]. A five-year follow-up study reported that fume exposure was associated with significantly decreased $\mathrm{FEV}_{1}$ among individuals with early-stage COPD [12]. These studies were conducted based on the young adults or the patients with a known diagnosis of COPD or a single industry or occupational category. By contrast, our study sought to address different questions. For instance, we were more concerned whether the occupational exposure to VGDF would affect the lung function both in the whole population. Second, we probed into the hypothesis whether the adverse effects of dual occupational exposure to dust and gas/vapor/fume on lung function would be synergistic. Moreover, we also sought to identify the gender disparity in lung function impairment among population exposed to VGDF. From the standpoint of the study design, our study has included a more heterogeneous sample of older persons. These findings highlighted the role of VGDF exposure might elevate small airway resistance, resulting in the pathogenesis of COPD [39]. We found lower FEV ${ }_{1} / F V C$ in females than in males, indicating that females might be more susceptible to the adverse impact of occupational exposure to VGDF. In particular, we found a greater magnitude of lung function impairment among those who had ever exposed to gas/vapor/fume only, rather than dual occupational exposure to VDGF. A more heterogeneous characteristic of each occupational exposure groups including age [23], duration of exposure and the improvement of working conditions [24,25] might have collectively explained the cumulative effect of different occupational exposure groups, which shed light on the results in this study. Our study was not designed to specifically address the plausible mechanisms how VGDF exposure could dampen the lung function. We speculated different mechanisms leading to lung function impairment related to different kinds of VGDF, depending on the affected biochemical pathways as well as the vapor and aerosol droplet size.

The study has certain limitations. First, the prevalence of chronic bronchitis in females $(0.77 \%)$ was markedly lower than in males (3.63\%), thereby decreasing the statistical power to detect the associations in females. Future study which recruit more women and more comprehensively assess the effect modification by gender is needed. Second, the magnitude of association might have bias because the exposure and respiratory symptoms self-reported was subjective. However, the objective assessment of occupational exposure and the development of job exposure matrix are neither practical nor feasible in such a larger scale study like ours. Despite the aforementioned limitations, our study findings remained mostly robust because the estimated odds of chronic bronchitis has taken into account five stepwise models and has been subject to sensitivity analysis that included two methods of PS to determine the validity. The association of all models were not modified materially compared with the overall analysis. 


\section{Conclusions}

In conclusion, we have now provided the evidence regarding the association of occupational exposure to VGDF and CB and the individual respiratory symptoms. Occupational exposure to VGDF is associated with impaired lung function in the whole population. These findings highlight the role of VGDF in driving the pathogenesis and clinical presentation of COPD. Avoidance of these exposures is highly relevant for occupational prevention or control among the general population.

\section{Abbreviations}

COPD, chronic obstructive pulmonary disease; VGDF, vapors, gases, dust and fumes; $\mathrm{FEV}_{1}$, forced expiratory volume in one second; FVC;forced vital capacity; MMEF, maximal mid-expiratory flow.

\section{Declarations}

\section{Ethics approval and consent to participate}

The study protocol was approved by the ethics review committee of the National Center for Chronic and NonCommunicable Disease Control and Prevention, China Center for Disease Control and Prevention in 2015 and the ethics review committee of the Guangdong Provincial Center for Disease Control and Prevention in 2019. All the methods were performed in accordance with Declaration of Helsinki. All participants had provided written informed consent.

\section{Consent for publication}

Not applicable.

\section{Availability of data and materials}

The data generated during the study are not publicly available. They arecurrently being evaluated for additional results in preparation but not yet published. Data may be made available upon reasonable requestto the corresponding author.

\section{Competing interests}

The authors declare that they have no competing interests.

\section{Funding}

Guangdong provincial medical science and technology research funding (C2021083).

\section{Authors'contributions}

Chuan Li, Ni Xiao, Yanjun Xu, Ruilin Meng and Lifeng Lin conceived of the study and provided overall guidance. Xueyan Zheng, Yijin Zheng and Lifeng Lin prepared the first draft and finalized the manuscript based on comments from all other authors and reviewer feedback. Xueyan Zheng, Weijie Guan, Yijin Zheng, Tingting Liao, Li Liu, and Lifeng Lin played a key role in formulating the analysis. All other authors contributed to the analysis and reviewed the manuscript.

\section{Acknowledgments}

We thank Prof. Li-wen Fang and Dr. He-ling Bao (National Center for Chronic and Non-Communicable Disease Control and Prevention, Chinese Center for Disease Control and Prevention) for their organization and instruction of the program. 


\section{References}

1. GBD 2015 Disease and Injury Incidence and Prevalence Collaborators. Global, regional, and national incidence, prevalence, and years lived with disability for 310 diseases and injuries, 1990-2015: a systematic analysis for the Global Burden of Disease Study 2015. Lancet. Oct 8 2016;388(10053):1545-1602. doi:10.1016/s01406736(16)31678-6

2. GBD 2015 Mortality and Causes of Death Collaborators. Global, regional, and national life expectancy, all-cause mortality, and cause-specific mortality for 249 causes of death, 1980-2015: a systematic analysis for the Global Burden of Disease Study 2015. Lancet. Oct 8 2016;388(10053):1459-1544. doi:10.1016/s0140-6736(16)31012-1

3. Vogelmeier CF, Criner GJ, Martinez FJ, Anzueto A, Barnes PJ, Bourbeau J, et al. Global Strategy for the Diagnosis, Management, and Prevention of Chronic Obstructive Lung Disease 2017 Report. GOLD Executive Summary. Am J Respir Crit Care Med. Mar 1 2017;195(5):557-582. doi:10.1164/rccm.201701-0218PP

4. Kim V, Han MK, Vance GB, Make BJ, Newell JD, Hokanson JE, et al. The chronic bronchitic phenotype of COPD: an analysis of the COPDGene Study. Chest. Sep 2011;140(3):626-633. doi:10.1378/chest.10-2948

5. Woodruff PG, Barr RG, Bleecker E, Christenson SA, Couper D, Curtis JL, et al. Clinical Significance of Symptoms in Smokers with Preserved Pulmonary Function. New England Journal of Medicine. 2016/05/12 2016;374(19):18111821. doi:10.1056/NEJMoa1505971

6. de Marco R, Accordini S, Cerveri I, Corsico A, Antó JM, Künzli N, et al. Incidence of chronic obstructive pulmonary disease in a cohort of young adults according to the presence of chronic cough and phlegm. Am J Respir Crit Care Med. Jan 1 2007;175(1):32-9. doi:10.1164/rccm.200603-3810C

7. Allinson JP, Hardy R, Donaldson GC, Shaheen SO, Kuh D, Wedzicha JA. The Presence of Chronic Mucus Hypersecretion across Adult Life in Relation to Chronic Obstructive Pulmonary Disease Development. Am J Respir Crit Care Med. Mar 15 2016;193(6):662-72. doi:10.1164/rccm.201511-22100C

8. Holm M, Kim JL, Lillienberg L, Storaas T, Jögi R, Svanes C, et al. Incidence and prevalence of chronic bronchitis: impact of smoking and welding. The RHINE study. Int J Tuberc Lung Dis. Apr 2012;16(4):553-7.

doi:10.5588/ijtld.11.0288

9. Sunyer J, Zock JP, Kromhout H, Garcia-Esteban R, Radon K, Jarvis D, et al. Lung function decline, chronic bronchitis, and occupational exposures in young adults. Am J Respir Crit Care Med. Nov 1 2005;172(9):1139-45.

doi:10.1164/rccm.200504-6480C

10. Lytras $T$, Kogevinas $M$, Kromhout $H$, Carsin AE, Antó JM, Bentouhami $H$, et al. Occupational exposures and incidence of chronic bronchitis and related symptoms over two decades: the European Community Respiratory Health Survey. Occup Environ Med. Apr 2019;76(4):222-229. doi:10.1136/oemed-2018-105274

11. Humerfelt S, Gulsvik A, Skjaerven R, Nilssen S, Kvåle G, Sulheim O, et al. Decline in FEV1 and airflow limitation related to occupational exposures in men of an urban community. Eur Respir J. Sep 1993;6(8):1095-103.

12. Harber P, Tashkin DP, Simmons M, Crawford L, Hnizdo E, Connett J. Effect of occupational exposures on decline of lung function in early chronic obstructive pulmonary disease. Am J Respir Crit Care Med. Nov 15 2007;176(10):9941000. doi:10.1164/rccm.200605-7300C

13. Krzyzanowski M, Jedrychowski W, Wysocki M. Factors associated with the change in ventilatory function and the development of chronic obstructive pulmonary disease in a 13-year follow-up of the Cracow Study. Risk of chronic obstructive pulmonary disease. Am Rev Respir Dis. Nov 1986;134(5):1011-9. doi:10.1164/arrd.1986.134.5.1011

14. Lytras T, Kogevinas M, Kromhout H, Carsin AE, Antó JM, Bentouhami H, et al. Occupational exposures and 20-year incidence of COPD: the European Community Respiratory Health Survey. Thorax. Nov 2018;73(11):1008-1015. doi:10.1136/thoraxjnl-2017-211158 
15. Liao SY, Lin X, Christiani DC. Occupational exposures and longitudinal lung function decline. Am J Ind Med. Jan 2015;58(1):14-20. doi:10.1002/ajim.22389

16. Lindberg A, Jonsson AC, Rönmark E, Lundgren R, Larsson LG, Lundbäck B. Ten-year cumulative incidence of COPD and risk factors for incident disease in a symptomatic cohort. Chest. May 2005;127(5):1544-52. doi:10.1378/chest.127.5.1544

17. Zheng XY, Li ZL, Li C, Guan WJ, Li LX, Xu YJ. Effects of cigarette smoking and biomass fuel on lung function and respiratory symptoms in middle-aged adults and the elderly in Guangdong province, China: A cross-sectional study. Indoor Air. Sep 2020;30(5):860-871. doi:10.1111/ina.12671

18. American Thoracic Society. Standardization of Spirometry, 1994 Update. American Thoracic Society. Am J Respir Crit Care Med. Sep 1995;152(3):1107-36. doi:10.1164/ajrccm.152.3.7663792

19. Asher MI, Keil U, Anderson HR, Beasley R, Crane J, Martinez F, et al. International Study of Asthma and Allergies in Childhood (ISAAC): rationale and methods. Eur Respir J. Mar 1995;8(3):483-91. doi:10.1183/09031936.95.08030483

20. American Thoracic Society. Standards for the diagnosis and care of patients with chronic obstructive pulmonary disease (COPD) and asthma. Am Rev Respir Dis. Jul 1986;136(1):225-44. doi:10.1164/ajrccm/136.1.225

21. Lahousse L, Seys LJM, Joos GF, Franco OH, Stricker BH, Brusselle GG. Epidemiology and impact of chronic bronchitis in chronic obstructive pulmonary disease. Eur Respir J. Aug 2017;50(2)doi:10.1183/13993003.024702016

22. Blanc PD, Torén K. Occupation in chronic obstructive pulmonary disease and chronic bronchitis: an update. Int $J$ Tuberc Lung Dis. Mar 2007;11(3):251-7.

23. James AL, Palmer LJ, Kicic E, Maxwell PS, Lagan SE, Ryan GF, et al. Decline in lung function in the Busselton Health Study: the effects of asthma and cigarette smoking. Am J Respir Crit Care Med. Jan 15 2005;171(2):109-14. doi:10.1164/rccm.200402-2300C

24. Kromhout $\mathrm{H}$, Vermeulen R. Long-term trends in occupational exposure: Are they real? What causes them? What shall we do with them? Ann Occup Hyg. Aug 2000;44(5):325-7. doi:10.1093/annhyg/44.5.325

25. Vermeulen R, de Hartog J, Swuste P, Kromhout $H$. Trends in exposure to inhalable particulate and dermal contamination in the rubber manufacturing industry: effectiveness of control measures implemented over a nineyear period. Ann Occup Hyg. Aug 2000;44(5):343-54.

26. Irsigler GB, Visser PJ, Spangenberg PA. Asthma and chemical bronchitis in vanadium plant workers. Am J Ind Med. Apr 1999;35(4):366-74. doi:10.1002/(sici)1097-0274(199904)35:4<366::aid-ajim7>3.0.co;2-n

27. Nemery B. Metal toxicity and the respiratory tract. Eur Respir J. Feb 1990;3(2):202-19.

28. Yu D, Walters DM, Zhu L, Lee PK, Chen Y. Vanadium pentoxide $(\mathrm{V}(2) \mathrm{O}(5))$ induced mucin production by airway epithelium. Am J Physiol Lung Cell Mol Physiol. Jul 2011;301(1):L31-9. doi:10.1152/ajplung.00301.2010

29. Anyfantis ID, Rachiotis G, Hadjichristodoulou C, Gourgoulianis KI. Respiratory Symptoms and Lung Function among Greek Cotton Industry Workers: A Cross-Sectional Study. Int J Occup Environ Med. Jan 2017;8(1):32-38. doi:10.15171/ijoem.2017.888

30. Vedal S, Chan-Yeung M, Enarson D, Fera T, Maclean L, Tse KS, et al. Symptoms and pulmonary function in western red cedar workers related to duration of employment and dust exposure. Arch Environ Health. May-Jun 1986;41(3):179-83. doi:10.1080/00039896.1986.9935774

31. Senthilselvan A, Chénard L, Ulmer K, Gibson-Burlinguette N, Leuschen C, Dosman JA. Excess respiratory symptoms in full-time male and female workers in large-scale swine operations. Chest. Apr 2007;131(4):1197-204. doi:10.1378/chest.06-2323 
32. Christiani DC, Wang XR, Pan LD, Zhang HX, Sun BX, Dai H, et al. Longitudinal changes in pulmonary function and respiratory symptoms in cotton textile workers. A 15-yr follow-up study. Am J Respir Crit Care Med. Mar 2001;163(4):847-53. doi:10.1164/ajrccm.163.4.2006063

33. Eagan TM, Gulsvik A, Eide GE, Bakke PS. Remission of respiratory symptoms by smoking and occupational exposure in a cohort study. Eur Respir J. Apr 2004;23(4):589-94. doi:10.1183/09031936.04.00041204

34. Matheson MC, Benke G, Raven J, Sim MR, Kromhout H, Vermeulen R, et al. Biological dust exposure in the workplace is a risk factor for chronic obstructive pulmonary disease. Thorax. Aug 2005;60(8):645-51. doi:10.1136/thx.2004.035170

35. Rodríguez E, Ferrer J, Zock JP, Serra I, Antó JM, de Batlle J, et al. Lifetime occupational exposure to dusts, gases and fumes is associated with bronchitis symptoms and higher diffusion capacity in COPD patients. PLoS One. 2014;9(2):e88426. doi:10.1371/journal.pone.0088426

36. Zock JP, Sunyer J, Kogevinas M, Kromhout H, Burney P, Antó JM. Occupation, chronic bronchitis, and lung function in young adults. An international study. Am J Respir Crit Care Med. Jun 2001;163(7):1572-7. doi:10.1164/ajrccm.163.7.2004195

37. Torén K, Vikgren J, Olin AC, Rosengren A, Bergström G, Brandberg J. Occupational exposure to vapor, gas, dust, or fumes and chronic airflow limitation, COPD, and emphysema: the Swedish CArdioPulmonary Biolmage Study (SCAPIS pilot). Int J Chron Obstruct Pulmon Dis. 2017;12:3407-3413. doi:10.2147/copd.S144933

38. de Jong K, Boezen HM, Kromhout H, Vermeulen R, Postma DS, Vonk JM. Association of occupational pesticide exposure with accelerated longitudinal decline in lung function. Am J Epidemiol. Jun 1 2014;179(11):1323-30. doi:10.1093/aje/kwu053

39. Oppenheimer BW, Goldring RM, Herberg ME, Hofer IS, Reyfman PA, Liautaud S, et al. Distal airway function in symptomatic subjects with normal spirometry following World Trade Center dust exposure. Chest. Oct 2007;132(4):1275-82. doi:10.1378/chest.07-0913

\section{Tables}

Table 1. Characteristics of the study population, as a function of household exposure to dust, gas, vapor and fumes 
Gas, vapor and fumes

\begin{tabular}{lllllllll} 
No & Yes & $P$ & No & Yes & $P$ & No & Yes & $P$ \\
\hline$(\mathrm{N}=4219)$ & $(\mathrm{N}=912)$ & & $(\mathrm{N}=4219)$ & $\begin{array}{l}(\mathrm{N}= \\
638)\end{array}$ & $(\mathrm{N}=4219)$ & $\begin{array}{l}(\mathrm{N}= \\
1649)\end{array}$ \\
\end{tabular}

\section{Social \\ demographic \\ indices (SDI)}

\begin{tabular}{|c|c|c|c|c|c|c|c|c|c|}
\hline Sex, n (\%) & & & $<0.001$ & & & 0.80 & & & $<0.001$ \\
\hline Male & $\begin{array}{l}2019 \\
(47.85)\end{array}$ & $\begin{array}{l}533 \\
(58.44)\end{array}$ & & $\begin{array}{l}2019 \\
(47.85)\end{array}$ & $\begin{array}{l}309 \\
(48.43)\end{array}$ & & $\begin{array}{l}2019 \\
(47.85)\end{array}$ & $\begin{array}{l}939 \\
(56.94)\end{array}$ & \\
\hline Female & $\begin{array}{l}2200 \\
(52.15)\end{array}$ & $\begin{array}{l}379 \\
(41.56)\end{array}$ & & $\begin{array}{l}2200 \\
(52.15)\end{array}$ & $\begin{array}{l}329 \\
(51.57)\end{array}$ & & $\begin{array}{l}2200 \\
(52.15)\end{array}$ & $\begin{array}{l}710 \\
(43.06)\end{array}$ & \\
\hline $\begin{array}{l}\text { Age (year), } \\
\text { mean (SD) }\end{array}$ & $\begin{array}{l}57.83 \\
(9.74)\end{array}$ & $\begin{array}{l}55.23 \\
(8.38)\end{array}$ & $<0.001$ & $\begin{array}{l}57.83 \\
(9.74)\end{array}$ & $\begin{array}{l}56.84 \\
(8.24)\end{array}$ & 0.01 & $\begin{array}{l}57.83 \\
(9.74)\end{array}$ & $\begin{array}{l}57.32 \\
(8.81)\end{array}$ & 0.05 \\
\hline $\begin{array}{l}\text { Educational } \\
\text { level, n (\%) }\end{array}$ & & & 0.20 & & & $<0.001$ & & & $<0.001$ \\
\hline $\begin{array}{l}\text { None + } \\
\text { primary school } \\
\text { education }\end{array}$ & $\begin{array}{l}2332 \\
(55.27)\end{array}$ & $\begin{array}{l}482 \\
(52.85)\end{array}$ & & $\begin{array}{l}2332 \\
(55.27)\end{array}$ & $\begin{array}{l}406 \\
(63.64)\end{array}$ & & $\begin{array}{l}2332 \\
(55.27)\end{array}$ & $\begin{array}{l}1046 \\
(63.43)\end{array}$ & \\
\hline $\begin{array}{l}\text { Middle school } \\
\text { education or } \\
\text { higher }\end{array}$ & $\begin{array}{l}1887 \\
(44.73)\end{array}$ & $\begin{array}{l}430 \\
(47.15)\end{array}$ & & $\begin{array}{l}1887 \\
(44.73)\end{array}$ & $\begin{array}{l}232 \\
(36.36)\end{array}$ & & $\begin{array}{l}1887 \\
(44.73)\end{array}$ & $\begin{array}{l}603 \\
(36.57)\end{array}$ & \\
\hline $\begin{array}{l}\text { Marriage } \\
\text { status, n (\%) }\end{array}$ & & & $<0.001$ & & & 0.06 & & & $<0.001$ \\
\hline Married & $\begin{array}{l}3796 \\
(89.97)\end{array}$ & $\begin{array}{l}853 \\
(93.53)\end{array}$ & & $\begin{array}{l}3796 \\
(89.97)\end{array}$ & $\begin{array}{l}589 \\
(92.32)\end{array}$ & & $\begin{array}{l}3796 \\
(89.97)\end{array}$ & $\begin{array}{l}1526 \\
(92.54)\end{array}$ & \\
\hline Unmarried & $\begin{array}{l}423 \\
(10.03)\end{array}$ & $\begin{array}{l}59 \\
(6.47)\end{array}$ & & $\begin{array}{l}423 \\
(10.03)\end{array}$ & $\begin{array}{l}49 \\
(7.68)\end{array}$ & & $\begin{array}{l}423 \\
(10.03)\end{array}$ & $\begin{array}{l}123 \\
(7.46)\end{array}$ & \\
\hline $\begin{array}{l}\text { Region of } \\
\text { residence, } n \\
\text { (\%) }\end{array}$ & & & 0.30 & & & $<0.001$ & & & $<0.001$ \\
\hline Urban & $\begin{array}{l}1729 \\
(40.98)\end{array}$ & $\begin{array}{l}392 \\
(42.98)\end{array}$ & & $\begin{array}{l}1729 \\
(40.98)\end{array}$ & $\begin{array}{l}143 \\
(22.41)\end{array}$ & & $\begin{array}{l}1729 \\
(40.98)\end{array}$ & $\begin{array}{l}490 \\
(29.71)\end{array}$ & \\
\hline Rural & $\begin{array}{l}2490 \\
(59.02)\end{array}$ & $\begin{array}{l}520 \\
(57.02)\end{array}$ & & $\begin{array}{l}2490 \\
(59.02)\end{array}$ & $\begin{array}{l}495 \\
(77.59)\end{array}$ & & $\begin{array}{l}2490 \\
(59.02)\end{array}$ & $\begin{array}{l}1159 \\
(70.29)\end{array}$ & \\
\hline Biomass fuel & & & 0.30 & & & $<0.001$ & & & $<0.001$ \\
\hline No & $\begin{array}{l}2678 \\
(66.75)\end{array}$ & $\begin{array}{l}569 \\
(65.03)\end{array}$ & & $\begin{array}{l}2678 \\
(66.75)\end{array}$ & $\begin{array}{l}307 \\
(49.44)\end{array}$ & & $\begin{array}{l}2678 \\
(66.75)\end{array}$ & $\begin{array}{l}697 \\
(43.24)\end{array}$ & \\
\hline Yes & $\begin{array}{l}1334 \\
(33.25)\end{array}$ & $\begin{array}{l}306 \\
(34.97)\end{array}$ & & $\begin{array}{l}1334 \\
(33.25)\end{array}$ & $\begin{array}{l}314 \\
(50.56)\end{array}$ & & $\begin{array}{l}1334 \\
(33.25)\end{array}$ & $\begin{array}{l}915 \\
(56.76)\end{array}$ & \\
\hline $\begin{array}{l}\text { Smoking, } \mathrm{n} \\
(\%)\end{array}$ & & & $<0.001$ & & & $>0.9$ & & & $<0.001$ \\
\hline No & $\begin{array}{l}2545 \\
(60.49)\end{array}$ & $\begin{array}{l}451 \\
(49.45)\end{array}$ & & $\begin{array}{l}2545 \\
(60.49)\end{array}$ & $\begin{array}{l}384 \\
(60.28)\end{array}$ & & $\begin{array}{l}2545 \\
(60.49)\end{array}$ & $\begin{array}{l}819 \\
(49.73)\end{array}$ & \\
\hline
\end{tabular}


Yes

\section{Symptoms, $\mathbf{n}$}

(\%)

\section{Chronic} bronchitis

No

No

Yes

Yes

Cough

No

Yes

Phlegm

No

Yes

Yes

\section{Anthropometry}

BMI $\left(\mathrm{kg} / \mathrm{m}^{2}\right)$,
mean (SD)

BMI category,

n (\%)

Under weight

Normal

Over weight

Obese

$$
\begin{aligned}
& 24.01 \\
& (3.85)
\end{aligned}
$$

$4143 \quad 892$

(98.20) (97.81)

$76(1.80) \quad 20$

(2.19)

$$
0.40
$$

0.90

\begin{tabular}{llll}
4143 & 626 & 4143 & 1591 \\
$(98.20)$ & $(98.12)$ & $(98.20)$ & $(96.48)$ \\
\hline $76(1.80)$ & 12 & $76(1.80)$ & 58 \\
& $(1.88)$ & & $(3.52)$
\end{tabular}

$<0.001$

\begin{tabular}{ll}
3950 & 822 \\
$(93.62)$ & $(90.13)$ \\
269 & 90 \\
$(6.38)$ & $(9.87)$ \\
\hline
\end{tabular}

$\begin{array}{ll}3950 & 578 \\ (93.62) & (90.60) \\ 269 & 60 \\ (6.38) & (9.40)\end{array}$

0.005

$<0.001$

\begin{tabular}{ll}
3792 & 774 \\
$(89.88)$ & $(84.87)$ \\
427 & 138 \\
$(10.12)$ & $(15.13)$ \\
\hline
\end{tabular}

(3.85)

$\begin{array}{ll}23.73 & 0.001 \\ (3.37) & \end{array}$

(3.37)

0.003
24.04
(3.92)

$\begin{array}{ll}3792 & 562 \\ (89.88) & (88.09)\end{array}$

$\begin{array}{ll}427 & 76 \\ (10.12) & (11.91)\end{array}$

0.20

$\begin{array}{ll}3950 & 1483 \\ (93.62) & (89.93) \\ 269 & 166 \\ (6.38) & (10.07)\end{array}$

0.20

$<0.001$ 


\begin{abstract}
After
bronchodilator

use, mean

(SD)
\end{abstract}

\begin{tabular}{llllllllll}
\hline FEV, L & 2.32 & 2.48 & $<0.001$ & 2.32 & 2.30 & 0.40 & 2.32 & 2.35 & 0.20 \\
& $(0.60)$ & $(0.56)$ & & $(0.60)$ & $(0.53)$ & & $(0.60)$ & $(0.59)$ & \\
\hline FVC, L & 2.93 & 3.13 & $<0.001$ & 2.93 & 2.96 & 0.40 & 2.93 & 3.02 & $<0.001$ \\
& $(0.73)$ & $(0.67)$ & & $(0.73)$ & $(0.66)$ & & $(0.73)$ & $(0.72)$ & \\
\hline FEV 1 /FVC & 79.53 & 79.46 & 0.80 & 79.53 & 78.17 & 0.002 & 79.53 & 78.01 & $<0.001$ \\
& $(8.74)$ & $(7.93)$ & & $(8.74)$ & $(8.51)$ & & $(8.74)$ & $(8.78)$ & \\
\hline MMEF, L/min & 2.26 & 2.38 & 0.002 & 2.26 & 2.10 & $<0.001$ & 2.26 & 2.17 & 0.005 \\
& $(0.96)$ & $(0.93)$ & & $(0.96)$ & $(0.89)$ & & $(0.96)$ & $(0.92)$ &
\end{tabular}

BMI: body mass index; SDI: social demographic indices; $\mathrm{FEV}_{1}$ : forced expiratory volume in one second; FVC: forced vital capacity; $F_{E V} / F V C$ : forced expiratory volume in one second/ forced vital capacity; MMEF: maximal mid-expiratory flow.

Table 2. The association between occupational exposure to dust and respiratory symptoms

\begin{tabular}{|c|c|c|c|c|c|c|c|}
\hline Variables & Exposure to dust & Chronic bronchitis & & Cough & & Phlegm & \\
\hline & & OR (95\%Cl) & $P$ & OR (95\%Cl) & $P$ & OR (95\%Cl) & $P$ \\
\hline \multirow[t]{2}{*}{ Model 1} & No & Reference & - & Reference & - & Reference & - \\
\hline & Yes & $1.22(0.72,1.97)$ & 0.43 & $1.61(1.25,2.06)$ & $<0.001$ & $1.58(1.28,1.94)$ & $<0.001$ \\
\hline \multirow[t]{2}{*}{ Model 2} & No & Reference & - & Reference & - & Reference & - \\
\hline & Yes & $1.27(0.74,2.07)$ & 0.36 & $1.56(1.2,2.01)$ & $<0.001$ & $1.50(1.2,1.85)$ & $<0.001$ \\
\hline \multirow[t]{2}{*}{ Model 3} & No & Reference & - & Reference & - & Reference & - \\
\hline & Yes & $1.32(0.77,2.17)$ & 0.28 & $1.6(1.23,2.07)$ & $<0.001$ & $1.54(1.24,1.91)$ & $<0.001$ \\
\hline \multirow[t]{2}{*}{ Model 4} & No & Reference & - & Reference & - & Reference & - \\
\hline & Yes & $1.30(0.76,2.13)$ & 0.32 & $1.56(1.2,2.01)$ & $<0.001$ & $1.50(1.21,1.86)$ & $<0.001$ \\
\hline \multirow[t]{2}{*}{ Model 5} & No & Reference & - & Reference & - & Reference & - \\
\hline & Yes & $1.34(0.78,2.22)$ & 0.26 & $1.60(1.22,2.08)$ & 0.001 & $1.49(1.19,1.85)$ & $<0.001$ \\
\hline \multirow[t]{2}{*}{ Model 6} & No & Reference & - & Reference & - & Reference & - \\
\hline & Yes & $1.25(0.73,2.04)$ & 0.39 & $1.53(1.18,1.97)$ & 0.001 & $1.48(1.20,1.83)$ & $<0.001$ \\
\hline \multirow[t]{2}{*}{ Model 7} & No & Reference & - & Reference & - & Reference & - \\
\hline & Yes & $1.2(0.71,2.02)$ & 0.49 & $1.48(1.14,1.92)$ & 0.003 & $1.43(1.15,1.78)$ & 0.001 \\
\hline
\end{tabular}

Model 1: Occupational exposure to dust; Model 2: Model 1 adjusted with the age, sex, education level, marriage status and region of residence; Model 3: Model 2 adjusted with the body-mass index; Model 4: Model 3 adjusted with smoking status; Model 5: Model 4 adjusted with biomass fuel; Model 6: Adjusted with propensity score scores; Model 7: Inverse probability of treatment weighting. 
Table 3. The association between occupational exposure to gas, vapor and fumes and respiratory symptoms

\begin{tabular}{|c|c|c|c|c|c|c|c|}
\hline \multirow[t]{2}{*}{ Variables } & \multirow{2}{*}{$\begin{array}{l}\text { Exposure to gas, vapor and } \\
\text { fumes }\end{array}$} & \multicolumn{2}{|c|}{ Chronic bronchitis } & \multicolumn{2}{|l|}{ Cough } & \multicolumn{2}{|l|}{ Phlegm } \\
\hline & & OR $(95 \% \mathrm{Cl})$ & $P$ & OR (95\%Cl) & $P$ & OR $(95 \% \mathrm{Cl})$ & $P$ \\
\hline \multirow[t]{2}{*}{ Model 1} & No & Reference & - & Reference & - & Reference & - \\
\hline & Yes & $\begin{array}{l}1.04(0.54 \\
1.86)\end{array}$ & 0.89 & $\begin{array}{l}1.52(1.13 \\
2.03)\end{array}$ & 0.01 & $\begin{array}{l}1.20(0.92, \\
1.55)\end{array}$ & 0.17 \\
\hline \multirow[t]{2}{*}{ Model 2} & No & Reference & - & Reference & - & Reference & - \\
\hline & Yes & $\begin{array}{l}1.03(0.53 \\
1.86)\end{array}$ & 0.91 & $\begin{array}{l}1.53(1.12 \\
2.05)\end{array}$ & 0.01 & $\begin{array}{l}1.25(0.95 \\
1.63)\end{array}$ & 0.10 \\
\hline \multirow[t]{2}{*}{ Model 3} & No & Reference & - & Reference & - & Reference & - \\
\hline & Yes & $\begin{array}{l}1.06(0.54 \\
1.92)\end{array}$ & 0.85 & $\begin{array}{l}1.56(1.15 \\
2.10)\end{array}$ & 0.004 & $\begin{array}{l}1.23(0.93 \\
1.61)\end{array}$ & 0.13 \\
\hline \multirow[t]{2}{*}{ Model 4} & No & Reference & - & Reference & - & Reference & - \\
\hline & Yes & $\begin{array}{l}1.07(0.54 \\
1.92)\end{array}$ & 0.84 & $\begin{array}{l}1.57(1.15 \\
2.12)\end{array}$ & 0.003 & $\begin{array}{l}1.24(0.94 \\
1.62)\end{array}$ & 0.12 \\
\hline \multirow[t]{2}{*}{ Model 5} & No & Reference & - & Reference & - & Reference & - \\
\hline & Yes & $\begin{array}{l}1.00(0.49 \\
1.83)\end{array}$ & 0.99 & $\begin{array}{l}1.53(1.11 \\
2.07)\end{array}$ & 0.008 & $\begin{array}{l}1.18(0.89 \\
1.56)\end{array}$ & 0.24 \\
\hline \multirow[t]{2}{*}{ Model 6} & No & Reference & - & Reference & - & Reference & - \\
\hline & Yes & $\begin{array}{l}1.05(0.53 \\
1.88)\end{array}$ & 0.88 & $\begin{array}{l}1.54(1.13 \\
2.06)\end{array}$ & 0.005 & $\begin{array}{l}1.23(0.94 \\
1.61)\end{array}$ & 0.12 \\
\hline \multirow[t]{2}{*}{ Model 7} & No & Reference & - & Reference & - & Reference & - \\
\hline & Yes & $\begin{array}{l}0.93(0.48 \\
1.81)\end{array}$ & 0.83 & $\begin{array}{l}1.42(1.04 \\
1.94)\end{array}$ & 0.03 & $\begin{array}{l}1.19(0.90 \\
1.58)\end{array}$ & 0.23 \\
\hline
\end{tabular}

Model 1: Occupational exposure to gas, vapor and fumes; Model 2: Model 1 adjusted with the age, sex, education level, marriage status and region of residence; Model 3: Model 2 adjusted with the body-mass index; Model 4: Model 3 adjusted with smoking status; Model 5: Model 4 adjusted with biomass fuel; Model 6: Adjusted with propensity score scores; Model 7: Inverse probability of treatment weighting.

Table 4. The association between occupational exposure to dust, gas, vapor and fumes and respiratory symptoms 


\begin{tabular}{|c|c|c|c|c|c|c|c|}
\hline \multirow[t]{2}{*}{ Variables } & \multirow{2}{*}{$\begin{array}{l}\text { Exposure to dust, gas, vapor } \\
\text { and fumes }\end{array}$} & \multicolumn{2}{|c|}{ Chronic bronchitis } & \multicolumn{2}{|l|}{ Cough } & \multicolumn{2}{|l|}{ Phlegm } \\
\hline & & OR $(95 \% \mathrm{Cl})$ & $P$ & OR $(95 \% \mathrm{Cl})$ & $P$ & $\begin{array}{l}\text { OR } \\
(95 \% \mathrm{Cl})\end{array}$ & $P$ \\
\hline \multirow[t]{2}{*}{ Model 1} & No & Reference & - & Reference & - & Reference & - \\
\hline & Yes & $\begin{array}{l}1.99(1.40 \\
2.81)\end{array}$ & $<0.001$ & $\begin{array}{l}1.64(1.34 \\
2.01)\end{array}$ & $<0.001$ & $\begin{array}{l}1.61(1.36, \\
1.9)\end{array}$ & $<0.001$ \\
\hline \multirow[t]{2}{*}{ Model 2} & No & Reference & - & Reference & - & Reference & - \\
\hline & Yes & $\begin{array}{l}1.80(1.26 \\
2.56)\end{array}$ & 0.001 & $\begin{array}{l}1.50(1.21 \\
1.84)\end{array}$ & $<0.001$ & $\begin{array}{l}1.51(1.27 \\
1.8)\end{array}$ & $<0.001$ \\
\hline \multirow[t]{2}{*}{ Model 3} & No & Reference & - & Reference & - & Reference & - \\
\hline & Yes & $\begin{array}{l}1.85(1.29 \\
2.64)\end{array}$ & $<0.001$ & $\begin{array}{l}1.50(1.21 \\
1.85)\end{array}$ & $<0.001$ & $\begin{array}{l}1.55(1.3 \\
1.84)\end{array}$ & $<0.001$ \\
\hline \multirow[t]{2}{*}{ Model 4} & No & Reference & - & Reference & - & Reference & - \\
\hline & Yes & $\begin{array}{l}1.79(1.25 \\
2.56)\end{array}$ & 0.001 & $\begin{array}{l}1.46(1.18 \\
1.80)\end{array}$ & $<0.001$ & $\begin{array}{l}1.51(1.27 \\
1.80)\end{array}$ & $<0.001$ \\
\hline \multirow[t]{2}{*}{ Model 5} & No & Reference & - & Reference & - & Reference & - \\
\hline & Yes & $\begin{array}{l}1.74(1.20 \\
2.52)\end{array}$ & 0.004 & $\begin{array}{l}1.43(1.15 \\
1.79)\end{array}$ & 0.001 & $\begin{array}{l}1.49(1.24 \\
1.79)\end{array}$ & $<0.001$ \\
\hline \multirow[t]{2}{*}{ Model 6} & No & Reference & - & Reference & - & Reference & - \\
\hline & Yes & $\begin{array}{l}1.71(1.19 \\
2.44)\end{array}$ & 0.003 & $\begin{array}{l}1.43(1.16 \\
1.76)\end{array}$ & $<0.001$ & $\begin{array}{l}1.49(1.25 \\
1.76)\end{array}$ & $<0.001$ \\
\hline \multirow[t]{2}{*}{ Model 7} & No & Reference & - & Reference & - & Reference & - \\
\hline & Yes & $\begin{array}{l}1.7(1.19 \\
2.45)\end{array}$ & 0.004 & $\begin{array}{l}1.45(1.16 \\
1.79)\end{array}$ & $<0.001$ & $\begin{array}{l}1.51(1.27 \\
1.80)\end{array}$ & $<0.001$ \\
\hline
\end{tabular}

Model 1: Occupational exposure to dust, gas, vapor and fumes; Model 2: Model 1 adjusted with the age, sex, education level, marriage status and region of residence; Model 3: Model 2 adjusted with the body-mass index; Model 4: Model 3 adjusted with smoking status; Model 5: Model 4 adjusted with biomass fuel; Model 6: Adjusted with propensity score scores; Model 7: Inverse probability of treatment weighting.

Table 5. The association between occupational exposure to dust and lung function 


\begin{tabular}{|c|c|c|c|c|c|c|c|c|c|}
\hline \multirow[t]{2}{*}{ Variables } & \multirow{2}{*}{$\begin{array}{l}\text { Exposure } \\
\text { to dust }\end{array}$} & \multicolumn{2}{|l|}{ FVC (L) } & \multicolumn{2}{|l|}{ FEV1 (L) } & \multicolumn{2}{|l|}{ FEV1/FVC } & \multicolumn{2}{|c|}{ MMEF (L/min) } \\
\hline & & $\beta(95 \% \mathrm{Cl})$ & $P$ & $\beta(95 \% \mathrm{Cl})$ & $P$ & $\beta(95 \% \mathrm{Cl})$ & $P$ & $\begin{array}{l}\beta(95 \% \\
\mathrm{Cl})\end{array}$ & $P$ \\
\hline \multirow[t]{2}{*}{ Model 1} & No & Reference & - & Reference & - & Reference & - & Reference & - \\
\hline & Yes & $\begin{array}{l}0.20(0.14, \\
0.26)\end{array}$ & $<0.001$ & $\begin{array}{l}0.16(0.11 \\
0.21)\end{array}$ & $<0.001$ & $\begin{array}{l}-0.08 \\
(-0.81 \\
0.65)\end{array}$ & 0.83 & $\begin{array}{l}0.12 \\
(0.04 \\
0.20)\end{array}$ & 0.003 \\
\hline \multirow[t]{2}{*}{ Model 2} & No & Reference & - & Reference & - & Reference & - & Reference & - \\
\hline & Yes & $\begin{array}{l}0.03(0.00 \\
0.06)\end{array}$ & 0.08 & $\begin{array}{l}0.02 \\
(-0.01 \\
0.05)\end{array}$ & 0.26 & $\begin{array}{l}-0.31 \\
(-0.95 \\
0.34)\end{array}$ & 0.35 & $\begin{array}{l}-0.02 \\
(-0.09 \\
0.05)\end{array}$ & 0.55 \\
\hline \multirow[t]{2}{*}{ Model 3} & No & Reference & - & Reference & - & Reference & - & Reference & - \\
\hline & Yes & $\begin{array}{l}0.03(0.00 \\
0.07)\end{array}$ & 0.07 & $\begin{array}{l}0.02 \\
(-0.01 \\
0.05)\end{array}$ & 0.21 & $\begin{array}{l}-0.27 \\
(-0.91 \\
0.38)\end{array}$ & 0.42 & $\begin{array}{l}-0.02 \\
(-0.09 \\
0.05)\end{array}$ & 0.62 \\
\hline \multirow[t]{2}{*}{ Model 4} & No & Reference & - & Reference & - & Reference & - & Reference & - \\
\hline & Yes & $\begin{array}{l}0.03(0.00 \\
0.07)\end{array}$ & 0.06 & $\begin{array}{l}0.02 \\
(-0.01 \\
0.05)\end{array}$ & 0.12 & $\begin{array}{l}-0.14 \\
(-0.79 \\
0.50)\end{array}$ & 0.66 & $\begin{array}{l}0.00 \\
(-0.07 \\
0.06)\end{array}$ & 0.93 \\
\hline \multirow[t]{2}{*}{ Model 5} & No & Reference & - & Reference & - & Reference & - & Reference & - \\
\hline & Yes & $\begin{array}{l}0.02(-0.01 \\
, 0.06)\end{array}$ & 0.16 & $\begin{array}{l}0.02 \\
(-0.01 \\
0.05)\end{array}$ & 0.25 & $\begin{array}{l}-0.16 \\
(-0.82 \\
0.49)\end{array}$ & 0.63 & $\begin{array}{l}-0.01 \\
(-0.08 \\
0.06)\end{array}$ & 0.80 \\
\hline \multirow[t]{2}{*}{ Model 6} & No & Reference & - & Reference & - & Reference & - & Reference & - \\
\hline & Yes & $\begin{array}{l}0.04(-0.01 \\
0.08)\end{array}$ & 0.15 & $\begin{array}{l}0.02 \\
(-0.02 \\
0.06)\end{array}$ & 0.24 & $\begin{array}{l}-0.22 \\
(-0.95 \\
0.51)\end{array}$ & 0.56 & $\begin{array}{l}-0.01 \\
(-0.08 \\
0.07)\end{array}$ & 0.83 \\
\hline \multirow[t]{2}{*}{ Model 7} & No & Reference & - & Reference & - & Reference & - & Reference & - \\
\hline & Yes & $\begin{array}{l}0.04(-0.02, \\
0.1)\end{array}$ & 0.17 & $\begin{array}{l}0.03 \\
(-0.03 \\
0.08)\end{array}$ & 0.33 & $\begin{array}{l}-0.37 \\
(-1.14 \\
0.40)\end{array}$ & 0.35 & $\begin{array}{l}-0.01 \\
(-0.09 \\
0.07)\end{array}$ & 0.80 \\
\hline
\end{tabular}

Model 1: Occupational exposure to dust; Model 2: Model 1 adjusted with the age, sex, height, education level, marriage status and region of residence; Model 3: Model 2 adjusted with the body-mass index; Model 4: Model 3 adjusted with smoking status; Model 5: Model 4 adjusted with biomass fuel; Model 6: Adjusted with propensity score scores; Model 7: Inverse probability of treatment weighting; FVC: forced vital capacity; FEV $_{\mathbf{1}}$ : forced expiratory volume in one second; MMEF: predicted value for maximal mid-expiratory flow.

Table 6. Effects of occupational exposure to gas, vapor and fumes on lung function 


\begin{tabular}{|c|c|c|c|c|c|c|c|c|c|}
\hline \multirow[t]{2}{*}{ Variables } & \multirow{2}{*}{$\begin{array}{l}\text { Exposure to } \\
\text { gas, vapor and } \\
\text { fumes }\end{array}$} & \multicolumn{2}{|l|}{ FVC (L) } & \multicolumn{2}{|l|}{ FEV1 (L) } & \multicolumn{2}{|l|}{$\mathrm{FEV}_{1} / \mathrm{FVC}$} & \multicolumn{2}{|c|}{ MMEF (L/min) } \\
\hline & & $\beta(95 \% \mathrm{Cl})$ & $P$ & $\beta(95 \% \mathrm{Cl})$ & $P$ & ${ }_{\mathrm{Cl})}^{\beta}(95 \%$ & $P$ & $\begin{array}{l}\beta(95 \% \\
\mathrm{Cl})\end{array}$ & $P$ \\
\hline \multirow[t]{2}{*}{ Model 1} & No & Reference & - & Reference & - & Reference & - & Reference & - \\
\hline & Yes & $\begin{array}{l}0.03 \\
(-0.04 \\
0.1)\end{array}$ & 0.44 & $\begin{array}{l}-0.02 \\
(-0.08 \\
0.04)\end{array}$ & 0.49 & $\begin{array}{l}-1.37 \\
(-2.25 \\
-0.48)\end{array}$ & 0.002 & $\begin{array}{l}-0.16 \\
(-0.25 \\
-0.06)\end{array}$ & 0.003 \\
\hline \multirow[t]{2}{*}{ Model 2} & No & Reference & - & Reference & - & Reference & - & Reference & - \\
\hline & Yes & $\begin{array}{l}0.01 \\
(-0.03 \\
0.05)\end{array}$ & 0.57 & $\begin{array}{l}-0.03 \\
(-0.07 \\
0.01)\end{array}$ & 0.13 & $\begin{array}{l}-1.18 \\
(-1.97 \\
-0.39)\end{array}$ & 0.003 & $\begin{array}{l}-0.16 \\
(-0.24 \\
-0.07)\end{array}$ & $<0.001$ \\
\hline \multirow[t]{2}{*}{ Model 3} & No & Reference & - & Reference & - & Reference & - & Reference & - \\
\hline & Yes & $\begin{array}{l}0.01 \\
(-0.03 \\
0.05)\end{array}$ & 0.50 & $\begin{array}{l}-0.03 \\
(-0.06 \\
0.01)\end{array}$ & 0.18 & $\begin{array}{l}-1.12 \\
(-1.91 \\
-0.33)\end{array}$ & 0.005 & $\begin{array}{l}-0.15 \\
(-0.23 \\
-0.07)\end{array}$ & $<0.001$ \\
\hline \multirow[t]{2}{*}{ Model 4} & No & Reference & - & Reference & - & Reference & - & Reference & - \\
\hline & Yes & $\begin{array}{l}0.01 \\
(-0.03 \\
0.06)\end{array}$ & 0.50 & $\begin{array}{l}-0.03 \\
(-0.06 \\
0.01)\end{array}$ & 0.18 & $\begin{array}{l}-1.11 \\
(-1.89 \\
-0.33)\end{array}$ & 0.005 & $\begin{array}{l}-0.15 \\
(-0.23 \\
-0.07)\end{array}$ & $<0.001$ \\
\hline \multirow[t]{2}{*}{ Model 5} & No & Reference & - & Reference & - & Reference & - & Reference & - \\
\hline & Yes & $\begin{array}{l}0.01 \\
(-0.03 \\
0.05)\end{array}$ & 0.61 & $\begin{array}{l}-0.03 \\
(-0.06 \\
0.01)\end{array}$ & 0.18 & $\begin{array}{l}-1.05 \\
(-1.85 \\
-0.26)\end{array}$ & 0.01 & $\begin{array}{l}-0.15 \\
(-0.23 \\
-0.07)\end{array}$ & $<0.001$ \\
\hline \multirow[t]{2}{*}{ Model 6} & No & Reference & - & Reference & - & Reference & - & Reference & - \\
\hline & Yes & $\begin{array}{l}0.01 \\
(-0.07 \\
0.08)\end{array}$ & 0.86 & $\begin{array}{l}-0.04 \\
(-0.10 \\
0.02)\end{array}$ & 0.17 & $\begin{array}{l}-1.44 \\
(-2.34 \\
-0.55)\end{array}$ & 0.002 & $\begin{array}{l}-0.19 \\
(-0.28 \\
-0.09)\end{array}$ & $<0.001$ \\
\hline \multirow[t]{2}{*}{ Model 7} & No & Reference & - & Reference & - & Reference & - & Reference & - \\
\hline & Yes & $\begin{array}{l}0.02 \\
(-0.06, \\
0.09)\end{array}$ & 0.64 & $\begin{array}{l}-0.03 \\
(-0.09 \\
0.02)\end{array}$ & 0.25 & $\begin{array}{l}-1.56 \\
(-2.48 \\
-0.64)\end{array}$ & 0.001 & $\begin{array}{l}-0.20 \\
(-0.30 \\
-0.11)\end{array}$ & $<0.001$ \\
\hline
\end{tabular}

Model 1: Occupational exposure to gas, vapor and fumes; Model 2: Model 1 adjusted with the age, sex, height, education level, marriage status and region of residence; Model 3: Model 2 adjusted with the body-mass index; Model 4: Model 3 adjusted with smoking status; Model 5: Model 4 adjusted with biomass fuel; Model 6: Adjusted with propensity score scores; Model 7: Inverse probability of treatment weighting; FVC: forced vital capacity; FEV $_{1}$ : forced expiratory volume in one second; MMEF: predicted value for maximal mid-expiratory flow.

Table 7. Effects of occupational exposure to dust, gas, vapor and fumes on lung function 


\begin{tabular}{|c|c|c|c|c|c|c|c|c|c|}
\hline \multirow[t]{2}{*}{ Variables } & \multirow{2}{*}{$\begin{array}{l}\text { Exposure to } \\
\text { dust, gas, } \\
\text { vapor and } \\
\text { fumes }\end{array}$} & \multicolumn{2}{|l|}{ FVC (L) } & \multicolumn{2}{|l|}{ FEV1 (L) } & \multicolumn{2}{|l|}{$\mathrm{FEV}_{1} / \mathrm{FVC}$} & \multicolumn{2}{|c|}{ MMEF (L/min) } \\
\hline & & $\underset{\mathrm{Cl})}{\beta(95 \%}$ & $P$ & $\begin{array}{l}\beta(95 \% \\
\mathrm{Cl})\end{array}$ & $P$ & ${ }_{\mathrm{Cl})}^{\beta}(95 \%$ & $P$ & $\begin{array}{l}\beta(95 \% \\
\mathrm{Cl})\end{array}$ & $P$ \\
\hline \multirow[t]{2}{*}{ Model 1} & No & Reference & - & Reference & - & Reference & - & Reference & - \\
\hline & Yes & $\begin{array}{l}0.10 \\
(0.05 \\
0.15)\end{array}$ & $<0.001$ & $\begin{array}{l}0.03 \\
(-0.01 \\
0.07)\end{array}$ & 0.16 & $\begin{array}{l}-1.53 \\
(-2.12 \\
-0.94)\end{array}$ & $<0.001$ & $\begin{array}{l}-0.09 \\
(-0.15 \\
-0.03)\end{array}$ & 0.01 \\
\hline \multirow[t]{2}{*}{ Model 2} & No & Reference & - & Reference & - & Reference & - & Reference & - \\
\hline & Yes & $\begin{array}{l}0.05 \\
(0.02 \\
0.07)\end{array}$ & 0.001 & $\begin{array}{l}0.01 \\
(-0.02, \\
0.03)\end{array}$ & 0.60 & $\begin{array}{l}-0.91 \\
(-1.44 \\
-0.39)\end{array}$ & 0.001 & $\begin{array}{l}-0.07 \\
(-0.13 \\
-0.02)\end{array}$ & 0.01 \\
\hline \multirow[t]{2}{*}{ Model 3} & No & Reference & - & Reference & - & Reference & - & Reference & - \\
\hline & Yes & $\begin{array}{l}0.05 \\
(0.02 \\
0.08)\end{array}$ & $<0.001$ & $\begin{array}{l}0.01 \\
(-0.01 \\
0.03)\end{array}$ & 0.41 & $\begin{array}{l}-0.84 \\
(-1.36 \\
-0.31)\end{array}$ & 0.002 & $\begin{array}{l}-0.07 \\
(-0.12 \\
-0.01)\end{array}$ & 0.02 \\
\hline \multirow[t]{2}{*}{ Model 4} & No & Reference & - & Reference & - & Reference & - & Reference & - \\
\hline & Yes & $\begin{array}{l}0.05 \\
(0.02 \\
0.08)\end{array}$ & $<0.001$ & $\begin{array}{l}0.01 \\
(-0.01 \\
0.04)\end{array}$ & 0.24 & $\begin{array}{l}-0.73 \\
(-1.25 \\
-0.20)\end{array}$ & 0.01 & $\begin{array}{l}-0.05 \\
(-0.11 \\
0.00)\end{array}$ & 0.05 \\
\hline \multirow[t]{2}{*}{ Model 5} & No & Reference & - & Reference & - & Reference & - & Reference & - \\
\hline & Yes & $\begin{array}{l}0.04 \\
(0.01 \\
0.07)\end{array}$ & 0.004 & $\begin{array}{l}0.01 \\
(-0.02, \\
0.03)\end{array}$ & 0.61 & $\begin{array}{l}-0.74 \\
(-1.28 \\
-0.20)\end{array}$ & 0.01 & $\begin{array}{l}-0.06 \\
(-0.12 \\
-0.01)\end{array}$ & 0.03 \\
\hline \multirow[t]{2}{*}{ Model 6} & No & Reference & - & Reference & - & Reference & - & Reference & - \\
\hline & Yes & $\begin{array}{l}0.00 \\
(-0.04 \\
0.05)\end{array}$ & 0.91 & $\begin{array}{l}-0.03 \\
(-0.07 \\
0.01)\end{array}$ & 0.17 & $\begin{array}{l}-0.88 \\
(-1.46 \\
-0.29)\end{array}$ & 0.003 & $\begin{array}{l}-0.1 \\
(-0.16 \\
-0.03)\end{array}$ & 0.003 \\
\hline \multirow[t]{2}{*}{ Model 7} & No & Reference & - & Reference & - & Reference & - & Reference & - \\
\hline & Yes & $\begin{array}{l}0.00 \\
(-0.05 \\
0.05)\end{array}$ & 0.96 & $\begin{array}{l}-0.03 \\
(-0.07 \\
0.01)\end{array}$ & 0.14 & $\begin{array}{l}-0.84 \\
(-1.43 \\
-0.26)\end{array}$ & 0.01 & $\begin{array}{l}-0.1 \\
(-0.16 \\
-0.04)\end{array}$ & 0.001 \\
\hline
\end{tabular}

Model 1: Occupational exposure to dust, gas, vapor and fumes; Model 2: Model 1 adjusted with the age, sex, height, education level, marriage status and region of residence; Model 3: Model 2 adjusted with the body-mass index; Model 4: Model 3 adjusted with smoking status; Model 5: Model 4 adjusted with biomass fuel; Model 6: Adjusted with propensity score scores; Model 7: Inverse probability of treatment weighting; FVC: forced vital capacity; FEV $_{1}$ : forced expiratory volume in one second; MMEF: predicted value for maximal mid-expiratory flow.

\section{Panel 1}

Panel 1 is available in the Supplemental Files section.

\section{Figures}




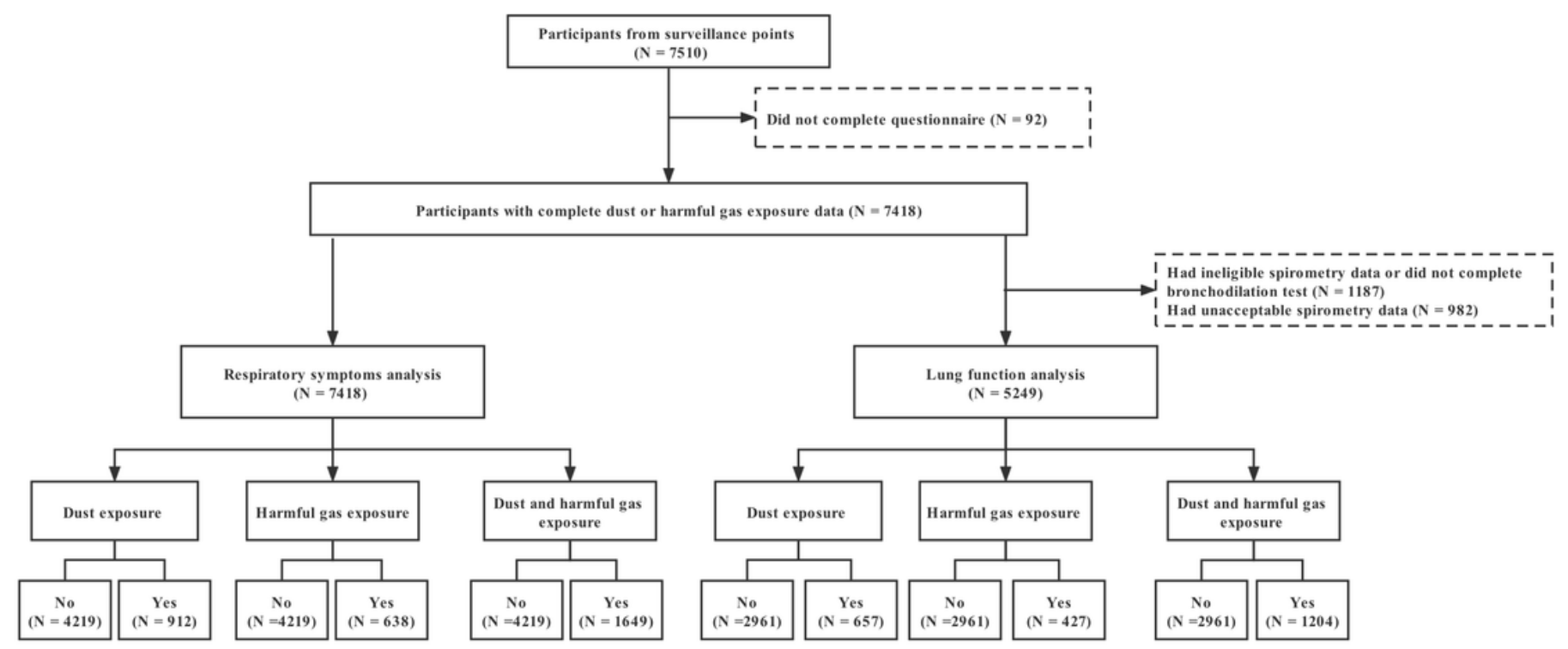

Figure 1

Flow chart of participant recruitment. 


\section{Chronic bronchitis}

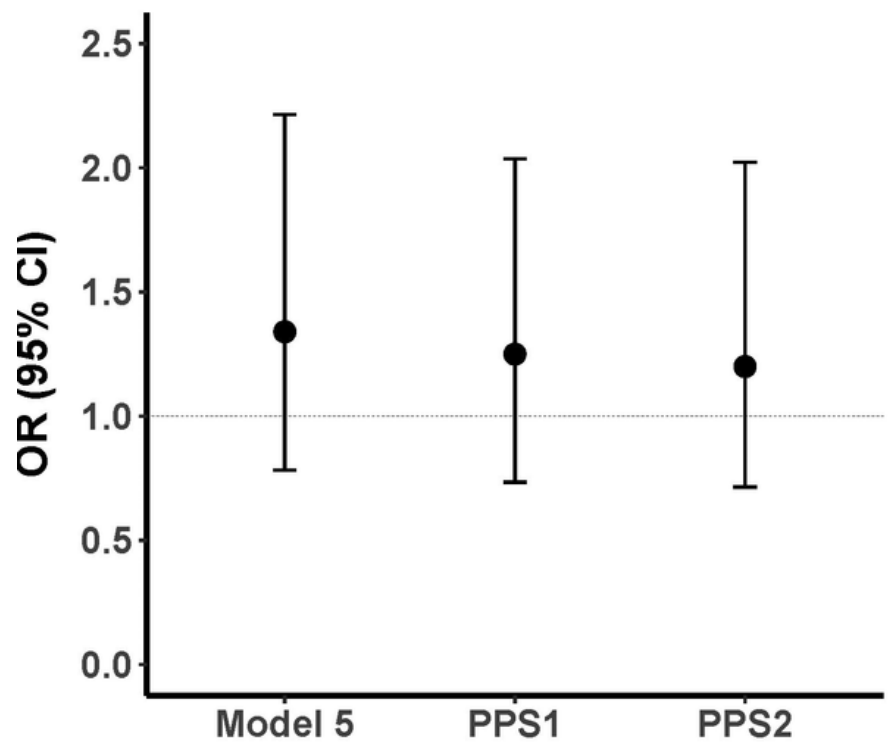

\section{Phlegm}

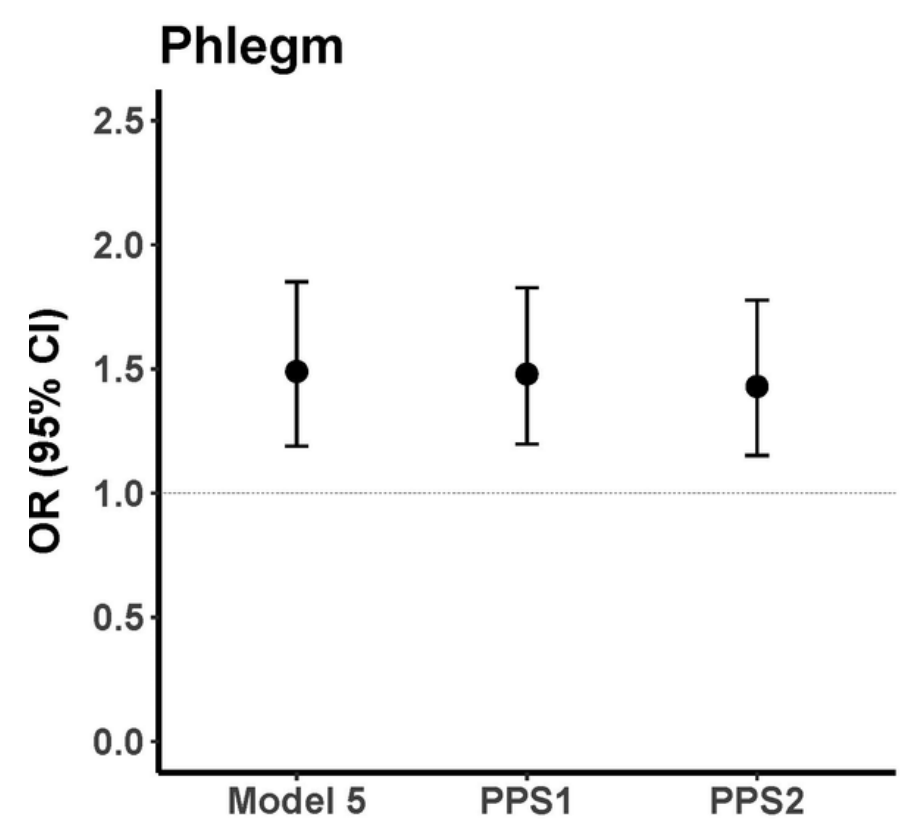

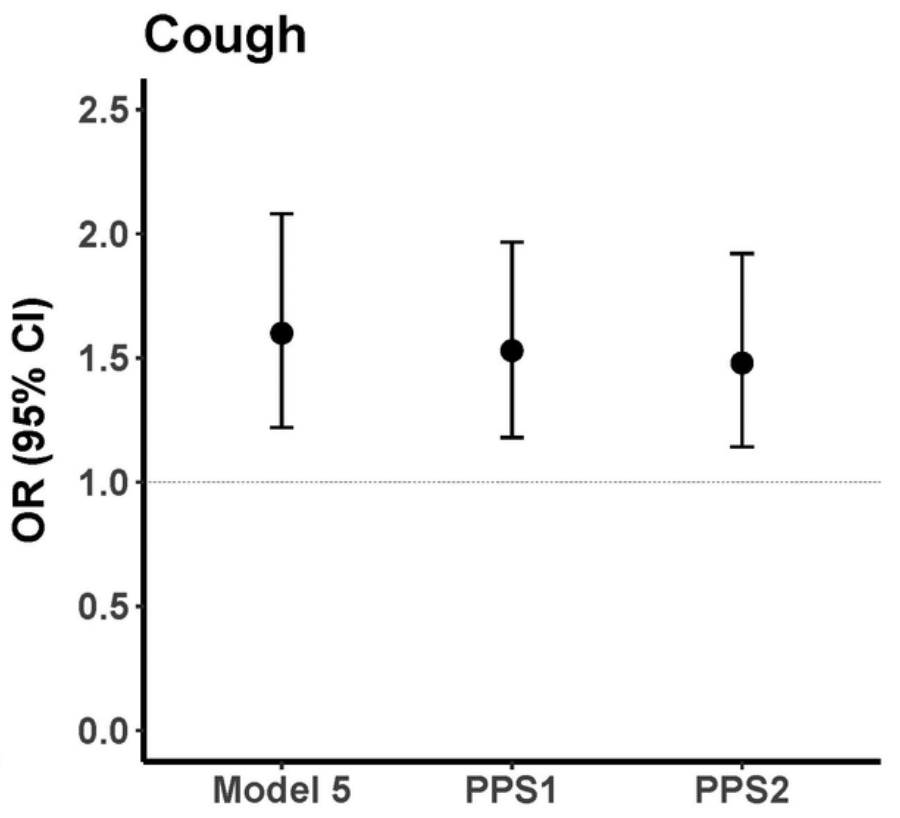

Figure 2

Effect estimates of exposure to dust on chronic bronchitis and the respiratory symptoms.

Model 5: Exposure to dust adjusted with the age, sex, education level, marriage status, region of residence, body-mass index, smoking status and biomass fuel;

PPS1: including the PS score as an additional covariate;

PPS2: Inverse probability weighting; 
Chronic bronchitis

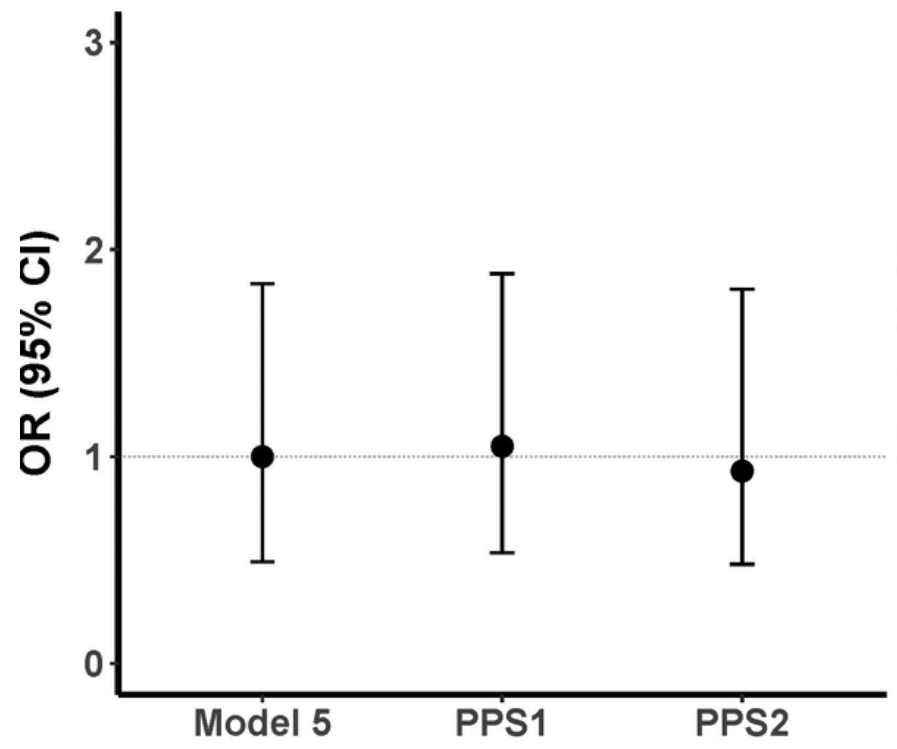

\section{Phlegm}

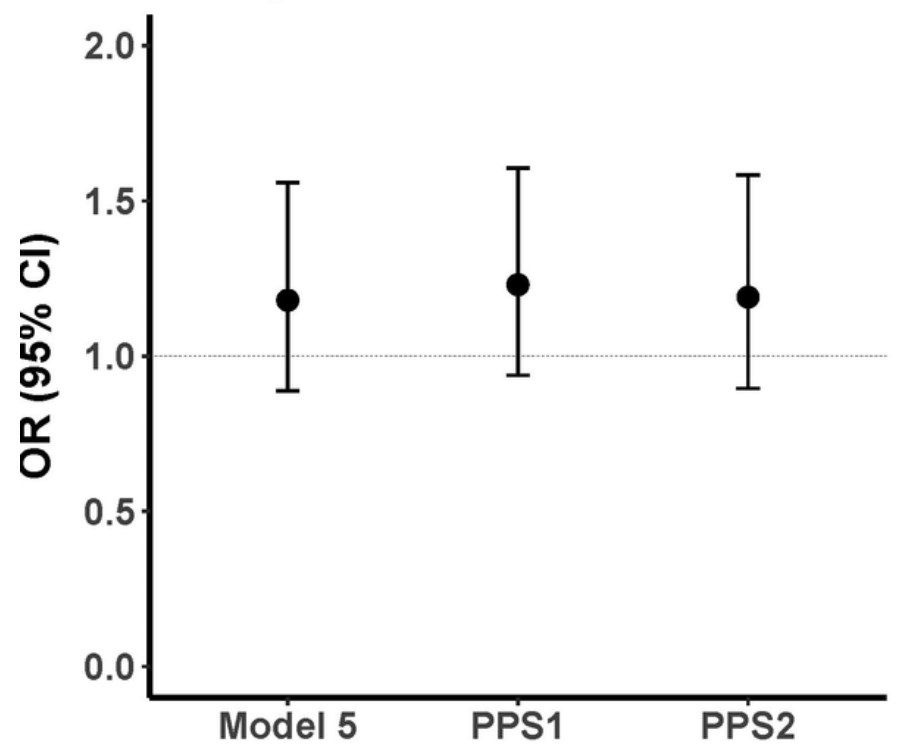

\section{Cough}

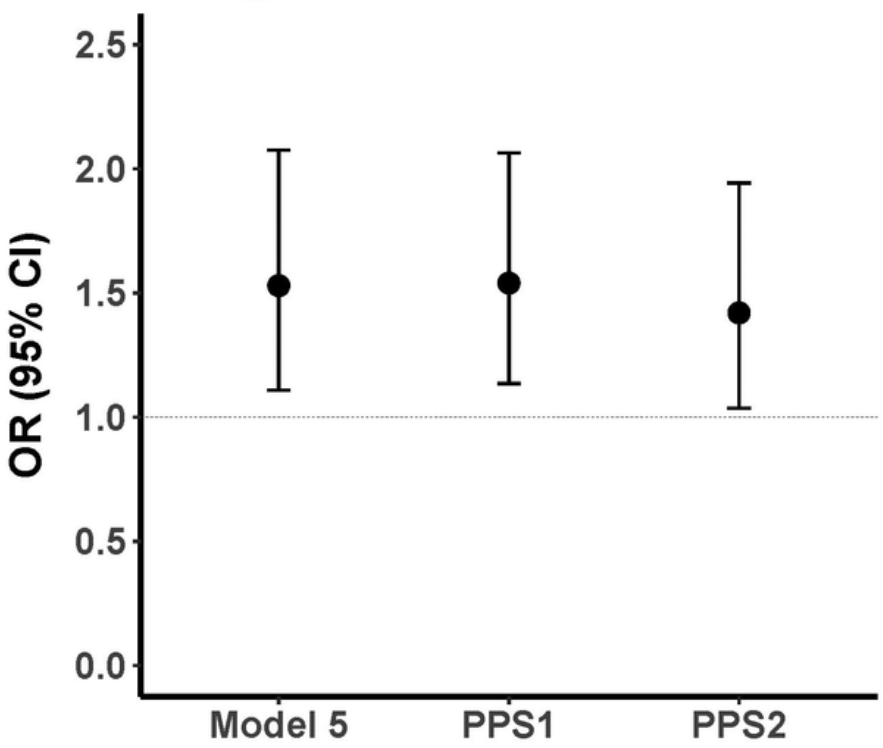

\section{Figure 3}

Effect estimates of exposure to gas, vapor and fumes on chronic bronchitis and respiratory symptoms.

Model 5: Exposure to gas, vapor and fumes adjusted with the age, sex, education level, marriage status, region of residence, body-mass index, smoking status and biomass fuel;

PPS1: including the PS score as an additional covariate;

PPS2: Inverse probability weighting; 
Chronic bronchitis

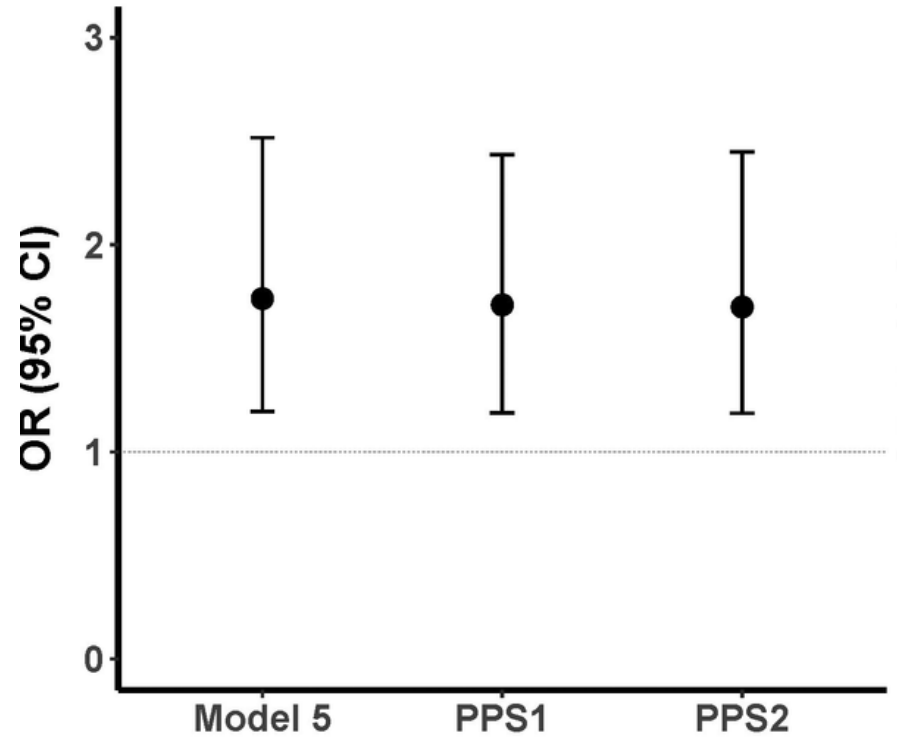

\section{Phlegm}

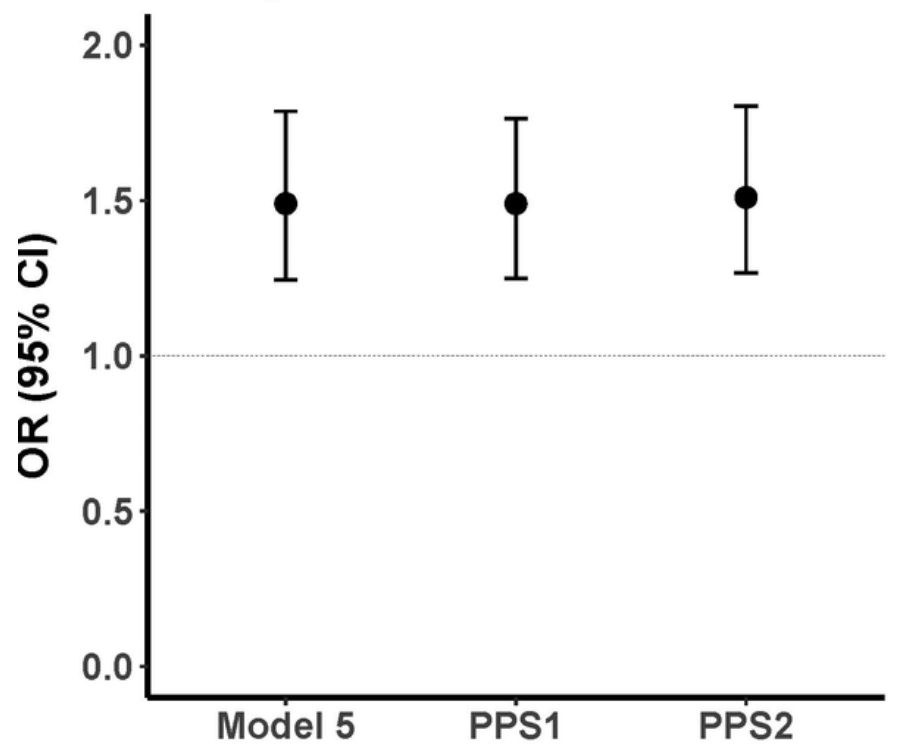

\section{Cough}

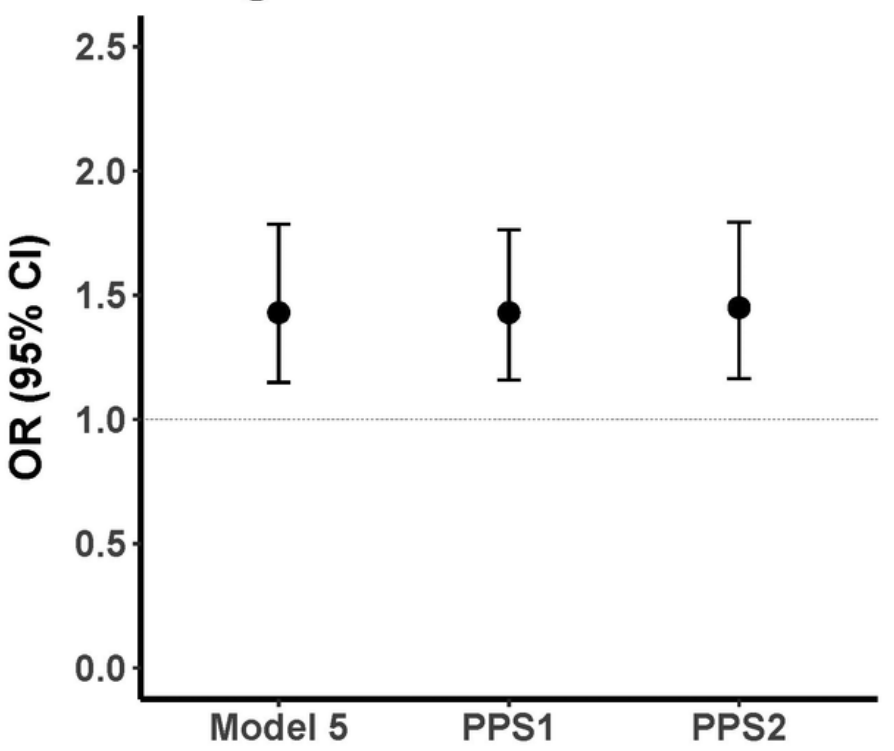

\section{Figure 4}

Effects of exposure to dust, gas, vapor and fumes on chronic bronchitis and the respiratory symptoms.

Model 5: Exposure to dust, gas, vapor and fumes adjusted with the age, sex, education level, marriage status, region of residence, body-mass index, smoking status and biomass fuel;

PPS1: including the PS score as an additional covariate;

PPS2: Inverse probability weighting; 
FVC (L)

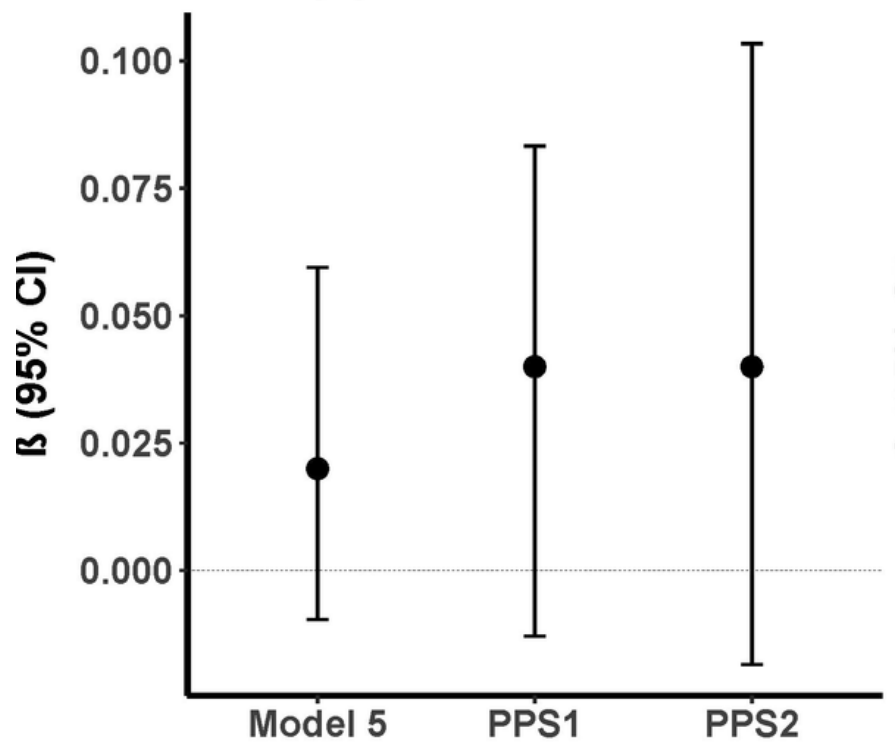

\section{FEV1/FVC}

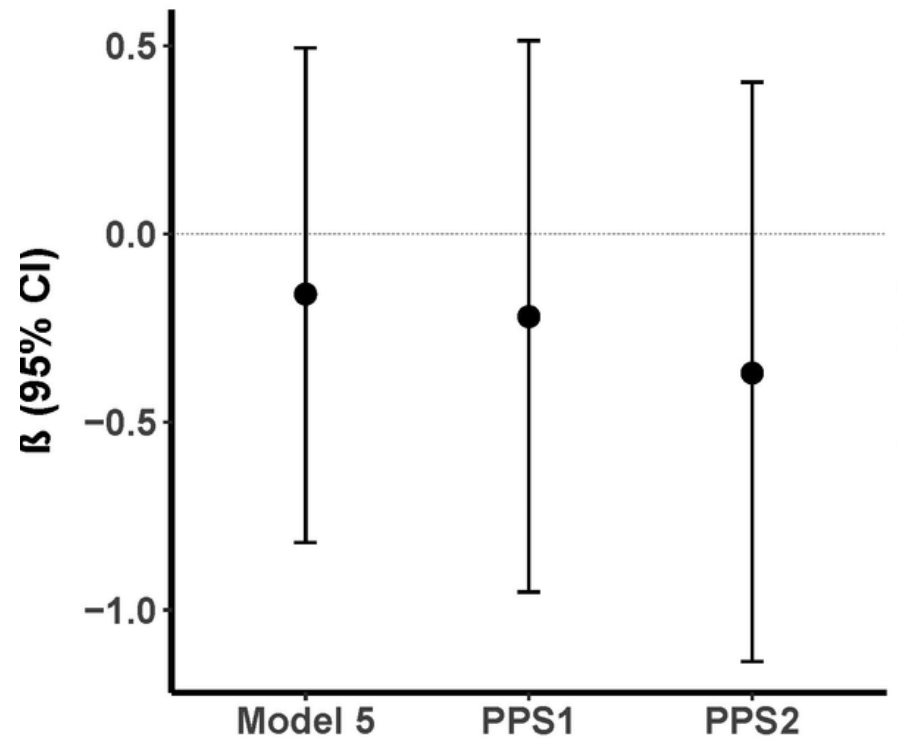

FEV1 (L)

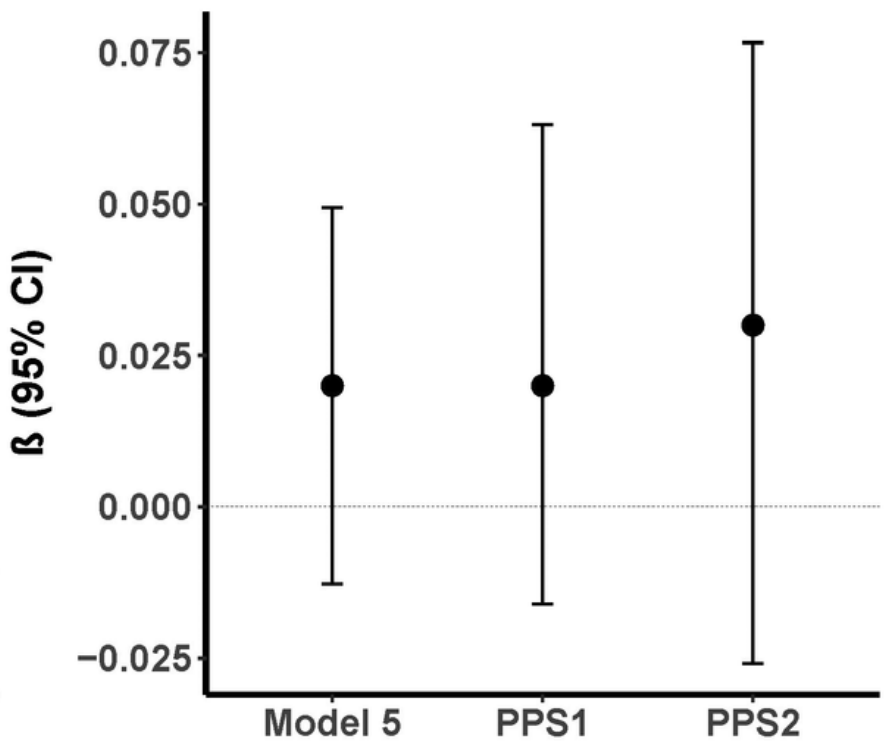

MMEF (L/min)

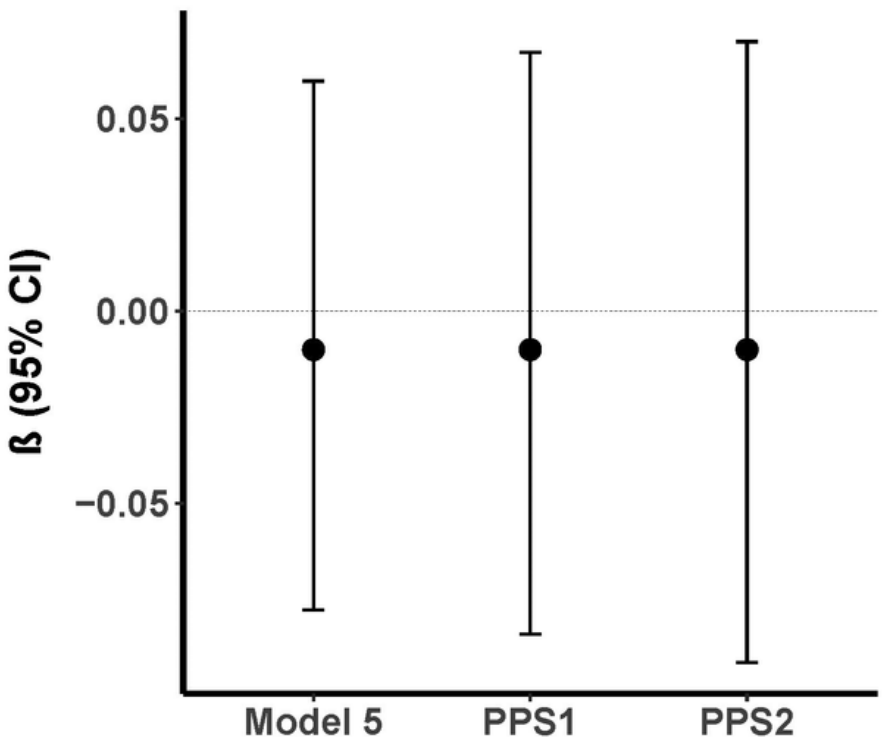

Figure 5

Effects of exposure to dust on lung function impairment.

Model 5: Exposure to dust adjusted with the age, sex, height, education level, marriage status, region of residence, bodymass index, smoking status and biomass fuel;

PPS1: including the PS score as an additional covariate;

PPS2: Inverse probability weighting; 
FVC (L)

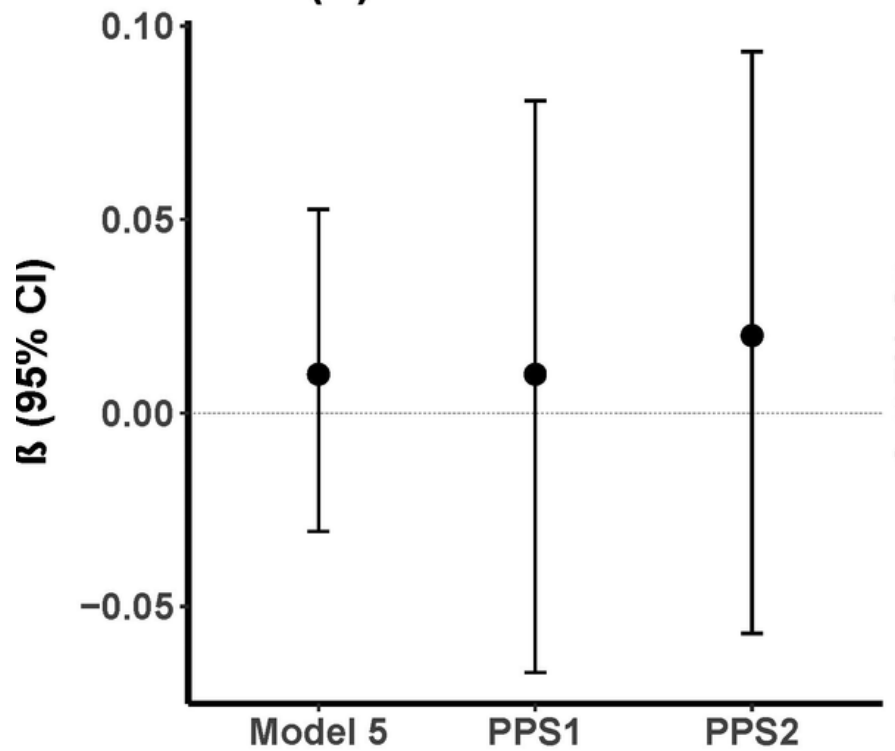

\section{FEV1/FVC}

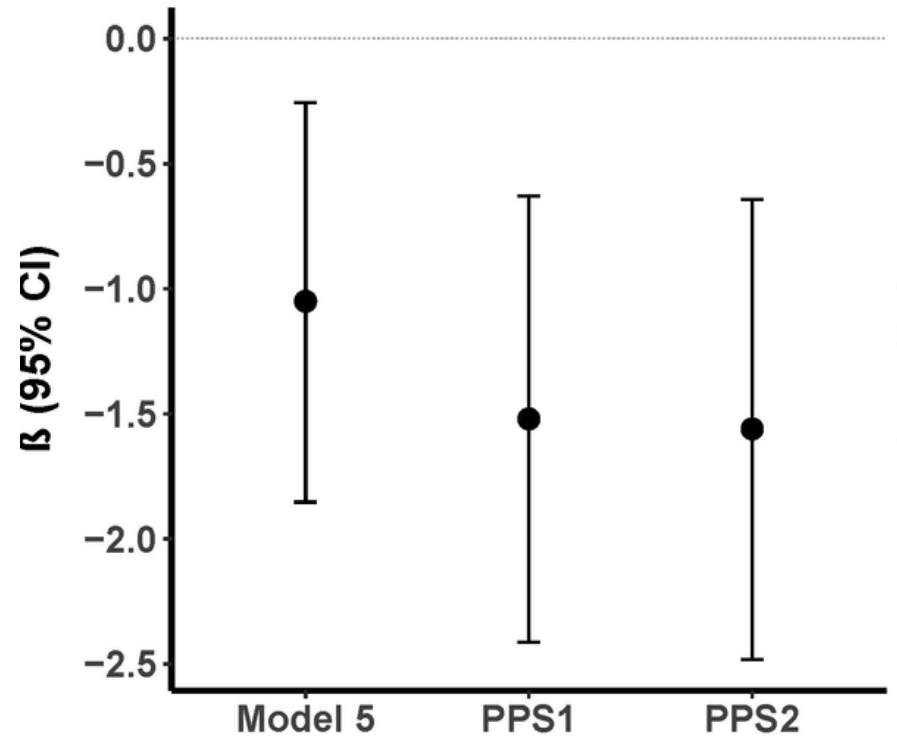

FEV1 (L)

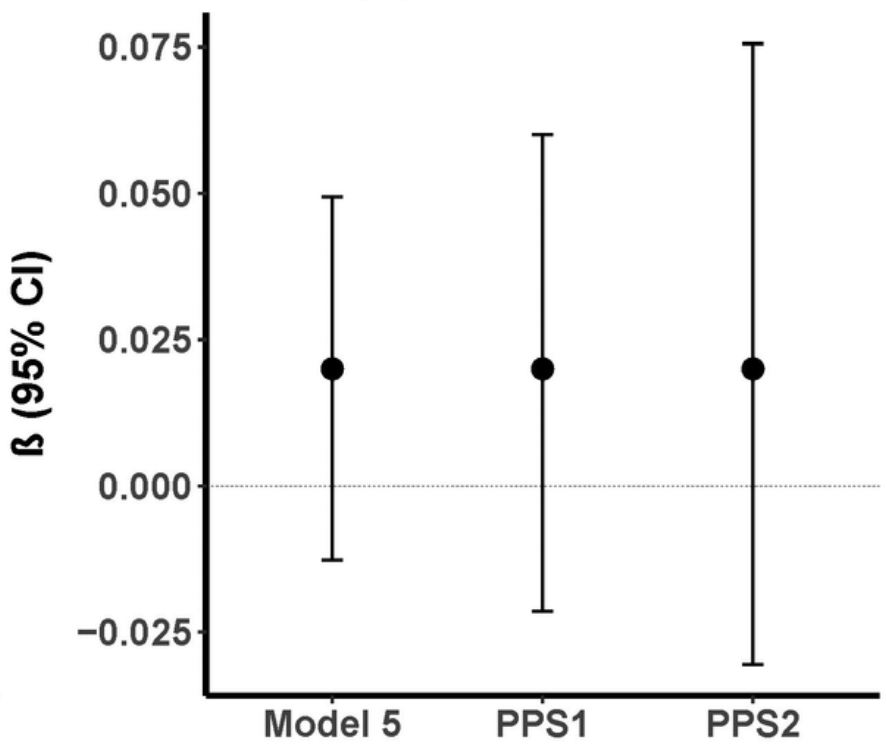

MMEF (L/min)

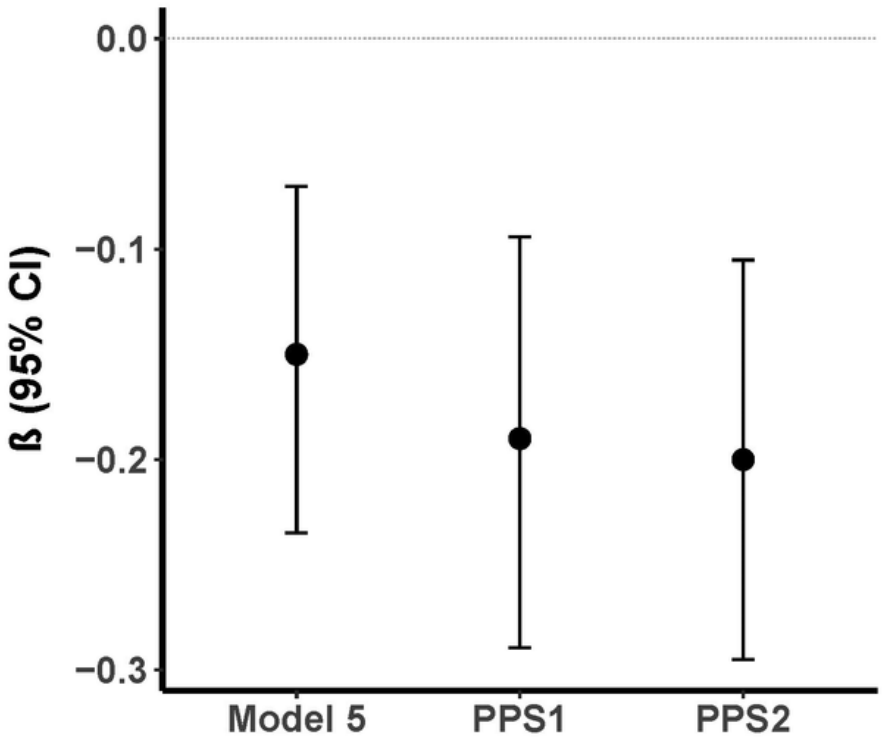

Figure 6

Effects of exposure to gas, vapor and fumes on lung function impairment.

Model 5: Exposure to gas, vapor and fumes adjusted with the age, sex, height, education level, marriage status, region of residence, body-mass index, smoking status and biomass fuel;

PPS1: including the PS score as an additional covariate;

PPS2: Inverse probability weighting; 
FVC (L)

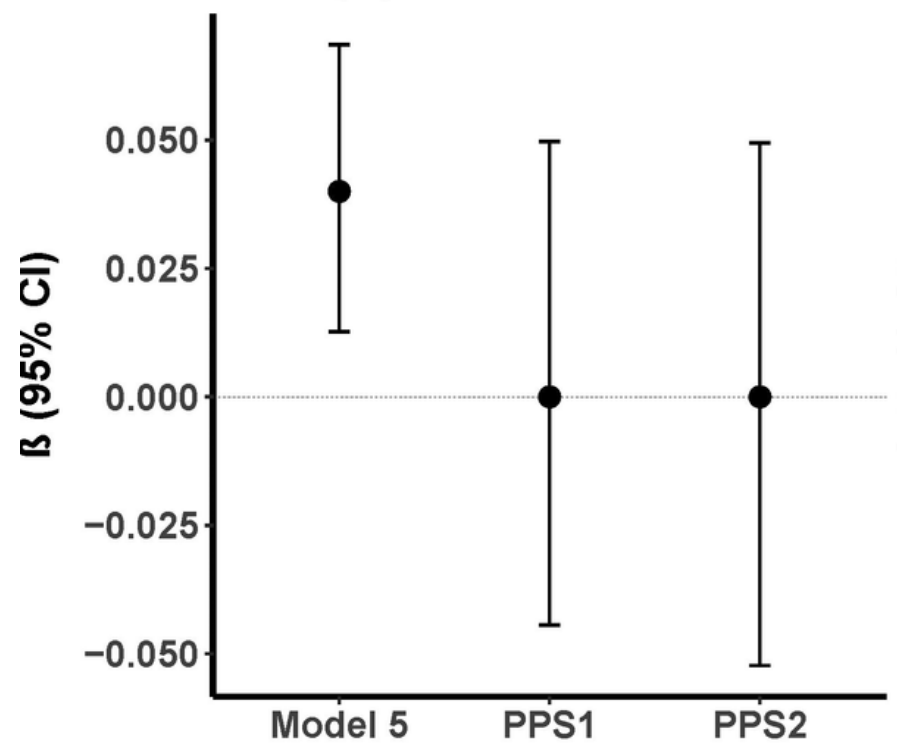

\section{FEV1/FVC}

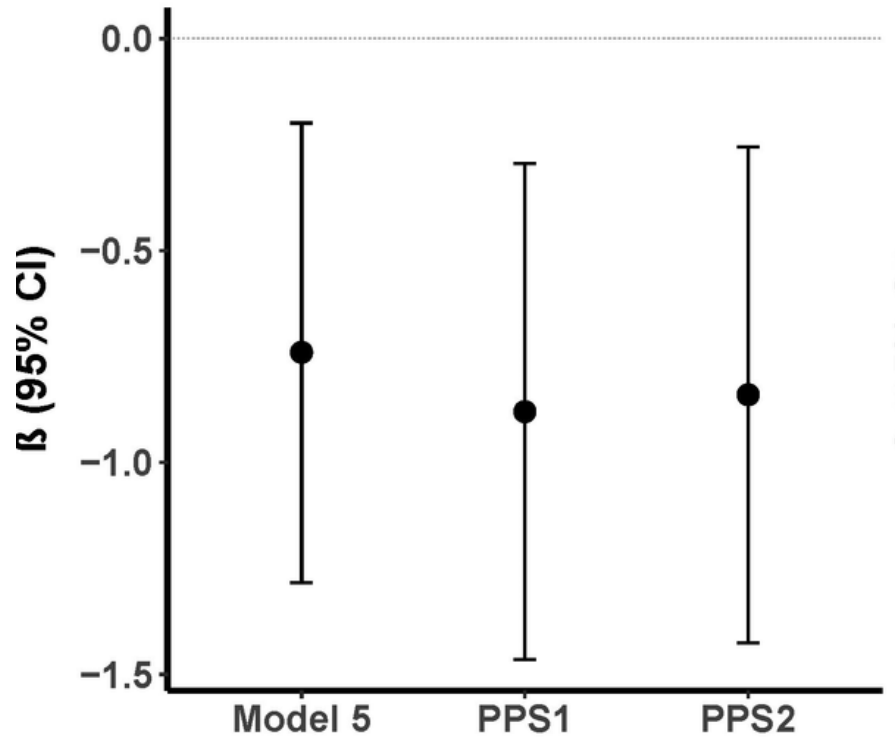

FEV1 (L)

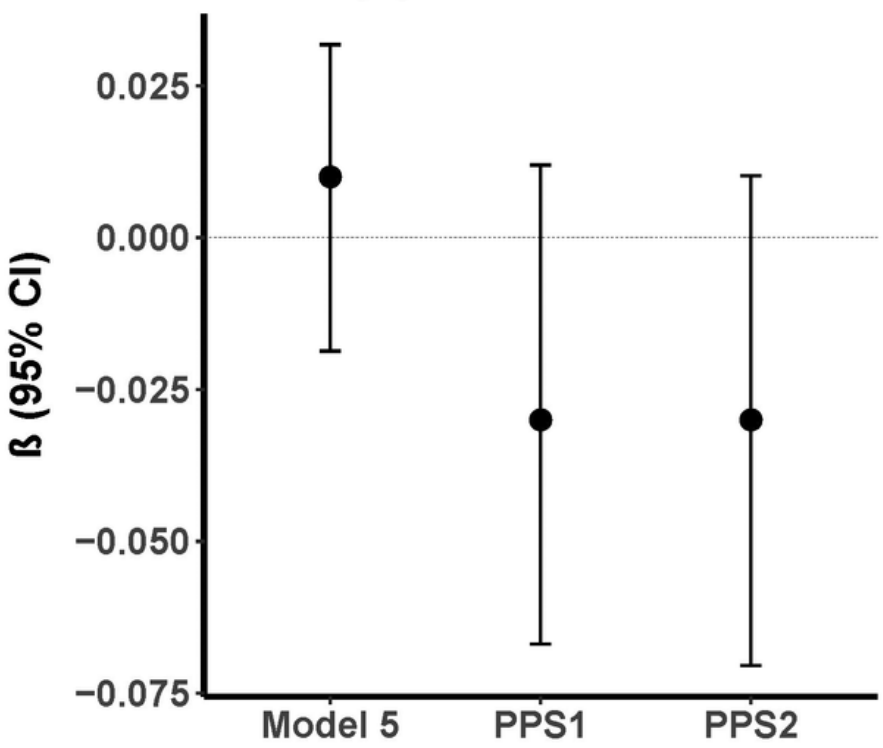

MMEF (L/min)

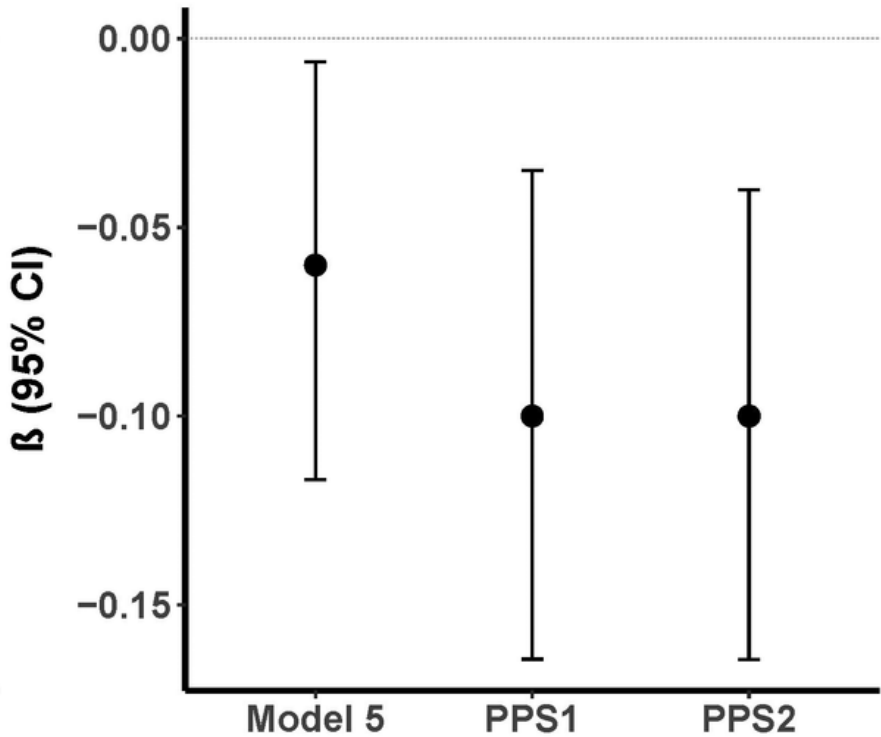

Figure 7

Effects of exposure to dust, gas, vapor and fumes on lung function impairment.

Model 5: Exposure to dust, gas, vapor and fumes adjusted with the age, sex, height, education level, marriage status, region of residence, body-mass index, smoking status and biomass fuel;

PPS1: including the PS score as an additional covariate;

PPS2: Inverse probability weighting;

\section{Supplementary Files}

This is a list of supplementary files associated with this preprint. Click to download. 
- supplementarymaterial.docx

- Panel1.docx 